This report was prepared as an account of work sponsored by an agency of the United States Government. Neither the United States Government nor any agency thereof, nor any of their employees, makes any warranty, express or implied, or assumes any legal liability or responsibility for the accuracy, completeness, or usefulness of any information, apparatus, product, or process disclosed, or represents that its use would not infringe privately owned rights. Reference herein to any specific commercial product, process, or service by trade name, trademark, manufacturer, or otherwise does not necessarily constitute or imply its endorsement, recommendation, or favoring by the United States Government or any agency thereof. The views and opinions of authors expressed herein do not necessarily state or reflect those of the United States Government or any agency thereof.
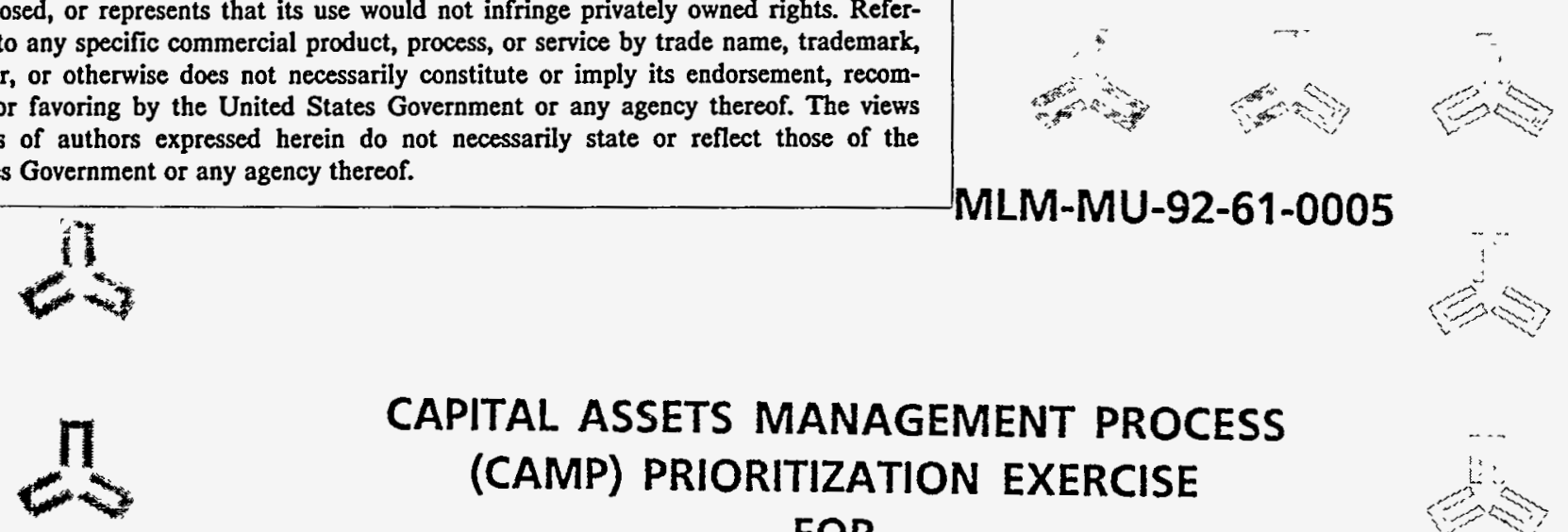

CAPITAL ASSETS MANAGEMENT PROCESS (CAMP) PRIORITIZATION EXERCISE FOR

FY 1994 AND FY 1995 PROJECTS

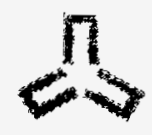

\author{
AT FIELD OFFICE, ALBUQUERQUE
}

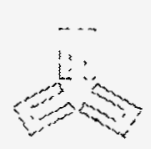

$\operatorname{lit}_{x \rightarrow \infty}$

January 16,1992

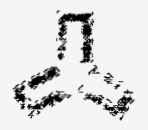

$$
\begin{gathered}
\text { PECLIV } \\
\text { JUL O } 1 \text { 1930 } \\
\text { OSTI }
\end{gathered}
$$

it

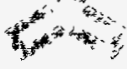

TEERG MOUND APPLIED TECHNOLOGIES

P.O. BOX 3000

MIAMISBURG, OHIO 45343-3000

$513-865-4020$

operated for the UNITED STATES DEPARTMENT OF ENERGY

Contract No. DE-AC04-88-DP43495 


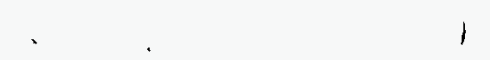

. 
This report was prepared as an account of work sponsored by an agency of the United States Government. Neither the United States Government nor any agency thereof, nor any of their employees, makes any warranty, express or implied, 'or assumes any legal liability or responsibility for the accuracy, completeness, or usefulness of any information, apparatus, product, or process disclosed, or represents that its use would not infringe privately owned rights. Reference herein to any specific commercial product, process, or service by trade name, trademark, manufacturer, or otherwise does not necessarily constitute or imply its endorsement, recommendation, or favoring by the United States Government or any agency thereof. The views and opinions of authors expressed herein do not necessarily state or reflect those of the United States Government or any agency thereof.

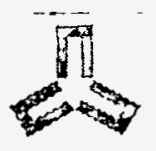<smiles>C1=C[C@H]2C=C[C@@H]1C2</smiles><smiles>C1=C[C@H]2C=C[C@@H]1[As]2</smiles><smiles>C1=C[C@H]2C[C@H]1[C@H]1C=C[C@@H]2C=C1</smiles>

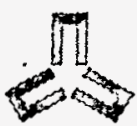<smiles>C1=CC2C=CC1C=C2</smiles>

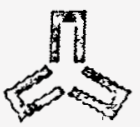

CAPITAL ASSETS MANAGEMENT PROCESS (CAMP) PRIORITIZATION EXERCISE FOR

\author{
FY 1994 AND FY 1995 PROJECTS
}

AT FIELD OFFIC̣E, ALBUQUERQUE

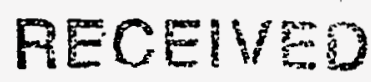

JUL 01.1998
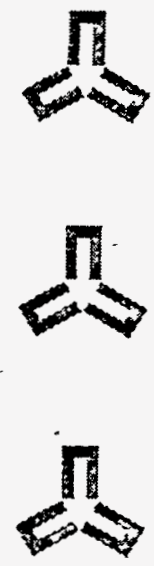

January 16, 1992<smiles>C[As]1CCCC1</smiles>

OSTI

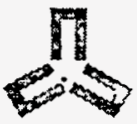

¿

P.O. BOX 3000

MIAMISBURG, OHIO 45343-3000

$513-865-4020$

operated for the UNITED STATES DEPARTMENT OF ENERGY

Contract No. DE-AC04-88-DP43495

DISTRIBUTION OFTHIS DOCUMENT IS UNLIMITED 



\section{DISCLAIMER}

Portions of this document may be illegible in electronic image products. Images are produced from the best available original document. 


\section{CAPITAL ASSETS MANAGEMENT PROCESS (CAMP)}

PRIORITIZATION EXERCISE FOR FY 1994 \& FY 1995 PROJECTS FIELD OFFICE, ALBUQUERQUE

\section{FY 1994 Projects}

Plant Life Safety Code Upgrades, Phase 1 T-Building Life Safety Code Upgrades Roads and Parking Lot Replacements Emergency Notification System Replacement, (92-D-126)

\section{FY 1995 Projects}

Reconfiguration of Inert Operations (FCAP) Steam and Condensate Systems Upgrades, (FCAP)

Site Drainage Control

TEC Rating Score

$\$ 2.3 \mathrm{M}$

$\$ 3.0 \mathrm{M}$

$\$ 2.2 \mathrm{M}$

$\$ 14.7 \mathrm{M}$

42.25

53

52

58
$\$ 3.8 \mathrm{M}$

$\$ 7.0 \mathrm{M}$

$\$ 17.3 \mathrm{M}$
52.5

51.5

50 

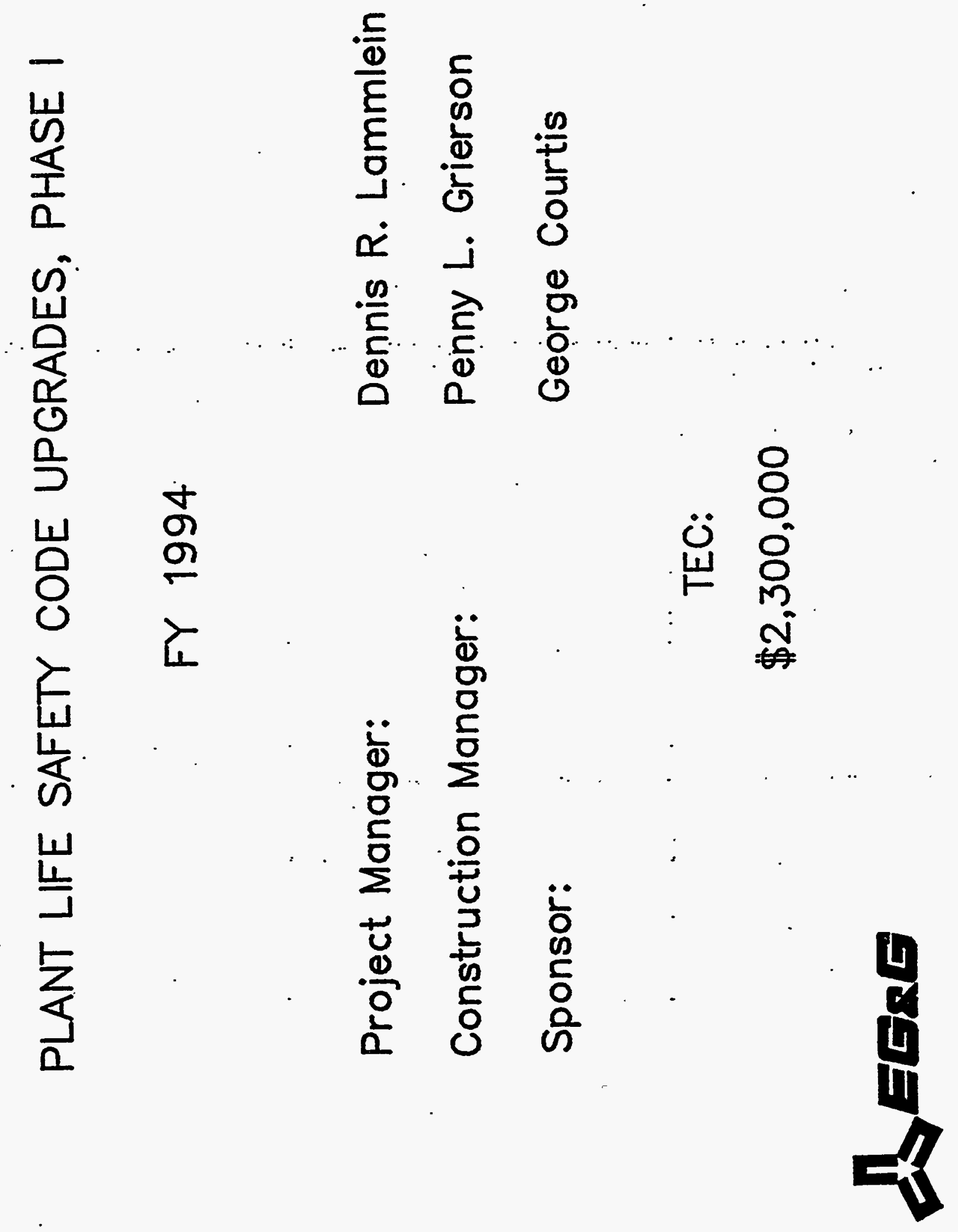


\section{PLANT LIFE SAFETY CODE UPGRADES, PHASE I \\ FY 1994}

Project Description:

- Building modifications to correct deficiencies -

- Egress Capacity

- Egress Arrangement

- Locks and Latches

- Signs and Marking of the Means of Egress

- Protection of the Means of Egress

- Subprojects developed geographically

- Typical floorplan attached

- Includes 15 buildings, covering over $50 \%$ of Mound square footage 


\section{PLANT LIFE SAFETY CODE UPGRADES, PHASE I FY 1994}

Justification:

EG\&G Safety Appraisals have noted Life Safety deficiencies in various buildings.

- Compliance with Life Safety Code (NFPA 101) required by DOE Order 6430.1A.

- Buildings do not meet current Life Safety Code. 


\section{PLANT LIFE SAFETY CODE UPGRADES, PHASE I}

\section{FY. 1994}

Funding Impacts:

- Project not funded:

- Buildings will be operated without meeting current Life Safety Codes, thus continuing the potential for a serious accident. 


\section{MOUND PRIORITIZATION RATIONALE \\ PLANT LIFE SAFETY CODE UPGRADES, PHASE I}

OVERALL RATING 42.3

HEALTH \& SAFETY - 35.

- Regulatory compliance - frequent minor violations (NFPA 101)

- Fire protection - standard industrial protection with acceptable risk

ENVIRONMENTAL/WASTE MANAGEMENT - 20

- N/A

SAFEGUARDS \& SECURITY - 20

- Minor problems unlikely

PROGRAMMATIC - 40

- Best management practice - many minor concerns

- Physical condition - adequate - meets mission; some corrective maintenance necessary 


\section{PLANT LIFE SAFETY. CODE UPGRADES, PHASE I}

\section{$\therefore$ FY 1994.}

Cost Estimate:

Engineering Design \& Inspection at Approximately

$\$ 250,000$ $15 \%$ of Construction Cost

Construction Cost

$\$ 1,690,000$

to

Standard Equipment

$\$ 0$

Contingency at Approximately $19 \%$ of Construction. $\$ 360,000$ Cost

Total Project Estimate

$\$ 2,300,000$ 


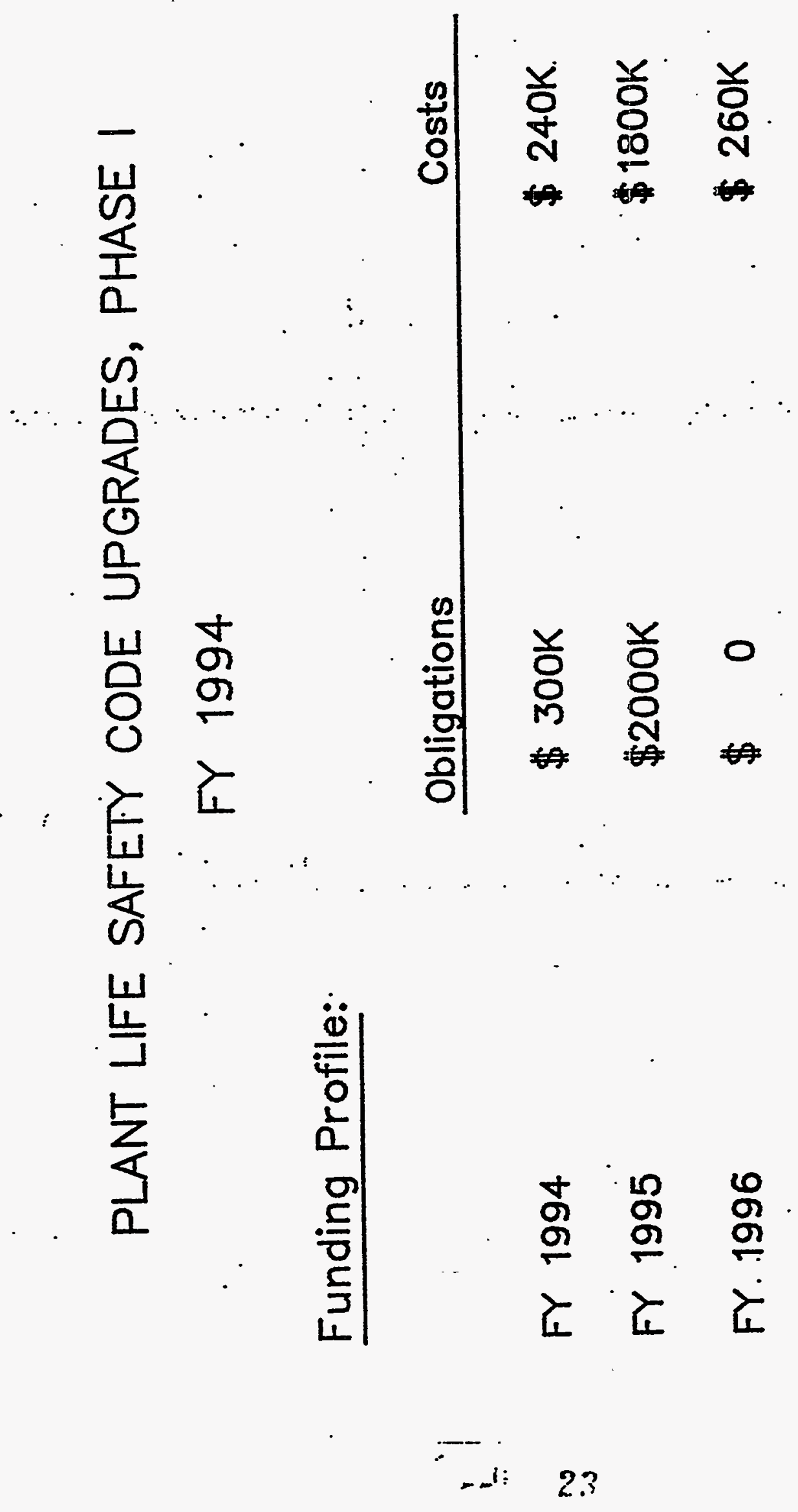




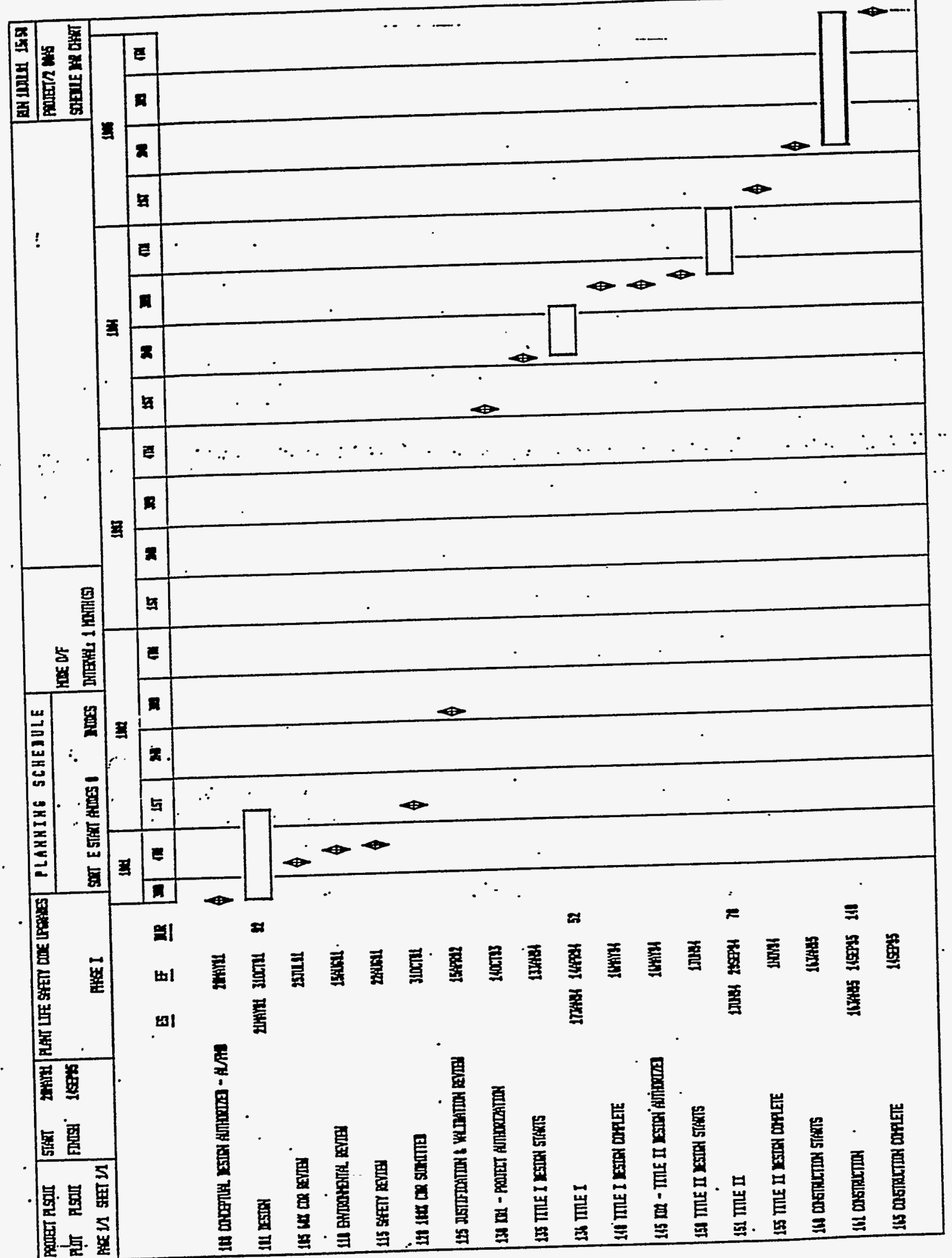

$x \quad 21$ 

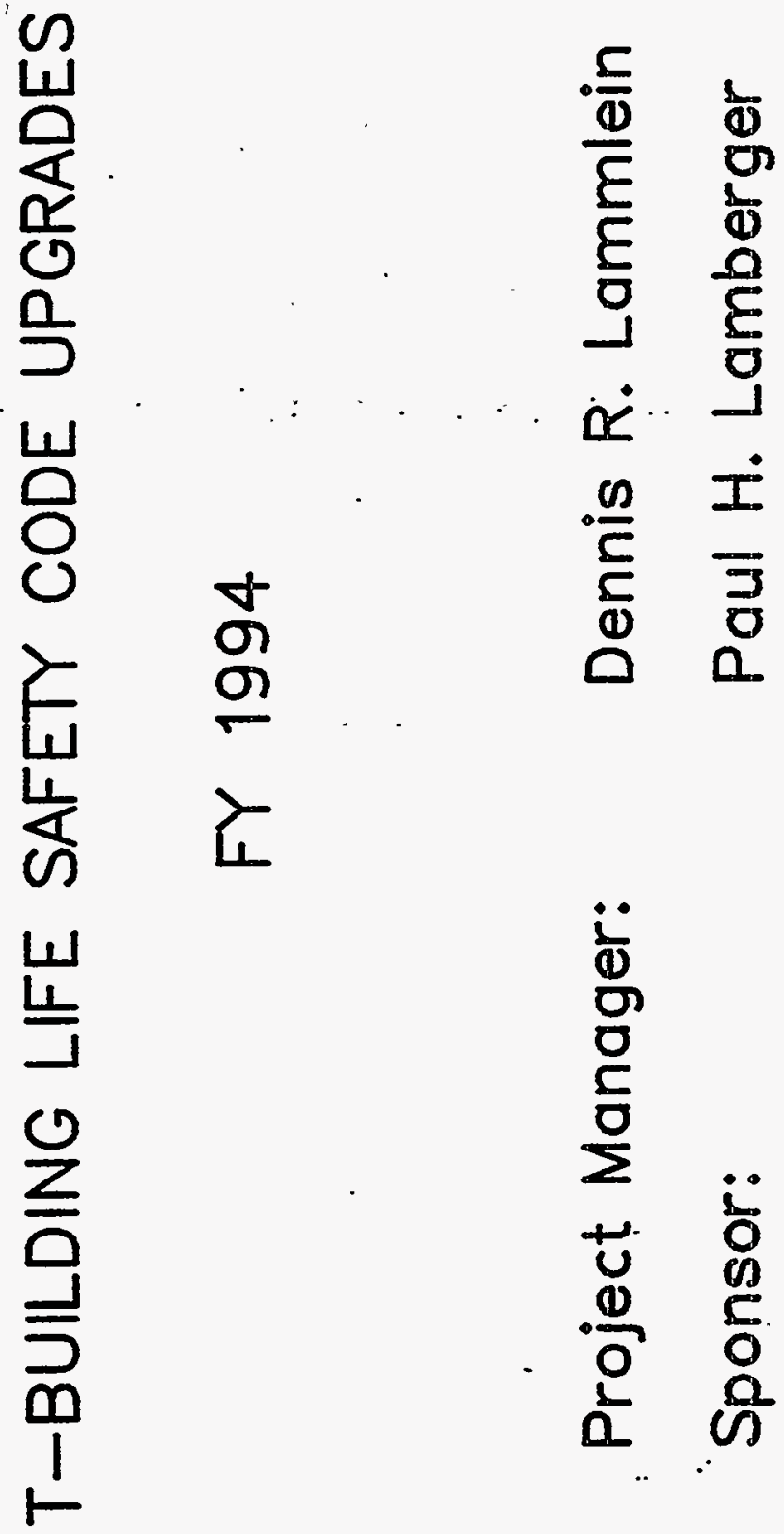

$\dot{\alpha}$.

$\begin{array}{cc}.0 & \dot{I} \\ & \overline{3} \\ \stackrel{5}{0} & 0 \\ 0 & 0\end{array}$

迎

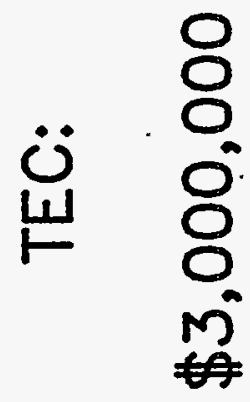

o

$\frac{8}{8}$

+

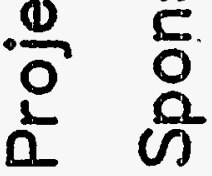

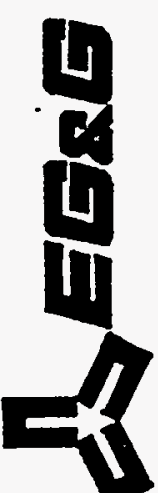




\section{T-BUILDING LIFE SAFETY CODE UPGRADES}

\section{FY 1994}

Project Description:

Project consists of six elements required to bring T-Building into full compliance with current Life Safety Code Regulations.

- Tunnel Upgrades

- Reduces potential fire hazard

- Facilitates personnel exit capacity, travel distance and means of egress in the tunnel

- Smoke Control

- Provides required ventilation in exit corridors

- Six air changes per hour 


\section{T-BUILDING LIFE SAFETY CODE UPGRADES FY 1994}

Project Description (continued):

- Emergency Lighting

- Upgrades emergency lighting to provide reliable source.

- Elevator Shaft Upgrades

- Provides for additional smoke detectors and sprinklers.

- Elevator Upgrades

- Provides elevator control features.

- First Floor Corridors

- Facilitates personnel exit capacity, travel distance and means of egress in the building proper. 


\section{T-BUILDING LIFE SAFETY CODE UPGRADES \\ FY 1994}

Justification:

Technical Safety Appraisal (TSA) noted Life Safety deficiencies in T-Building

- Compliance with Life Safety Code (NFPA 101) required by DOE Order 6430.1A.

- T Building does not meet current Life Safety Code (analyzed by John Sharry - 8/88)

- Exit capacity

- Travel distance

- Means of egress

- Fire protection

- Conceptual Design Report reviewed by John Sharry (1/91) and found to satisfy all the Life Safety requirements 


\section{T-BUILDING LIFE SAFETY CODE UPGRADES FY 1994}

Justification (continued):

Life Safety Code Upgrades necessary to ensure safe operation of the T-Building facility

- T-Building usage includes important operations such as: KYLE, TAWRS, HISS, TEDL, NDT, Safeguards and Calorimetry

- Future plans for T-Building include TERF and NFM 


\section{T-BUILDING LIFE SAFETY CODE UPGRADES}

\section{FY 1994}

Funding Impacts:

- Project not funded:

- T-Building will be operated without meeting current Life Safety Codes, thus continuing the potential for a serious accident.

- TSA finding will remain open.

- Partial funding: T-Building will be only partially upgraded. 


\section{MOUND PRIORITIZATION RATIONALE T-BUILDING LIFE SAFETY CODE UPGRADES}

\section{OVERALL RATING 53}

HEALTH \& SAFETY - 40

- Regulatory compliance - frequent minor violations (NFPA 101)

- Best management practice - many minor concerns

- Fire protection - standard industrial protection, with acceptable risk

ENVIRONMENTAL/WASTE: MANAGEMENT - 20

- N/A

SAFEGUARDS \& SECURITY - 30

- Best management practice - some minor concerns

PROGRAMMATIC - 50

- Compliance with orders - frequently in compliance, but serious violations occasionally occur

- Best management practice - some significant concerns 


\section{T-BUILDING LIFE SAFETY CODE UPGRADES}

\section{FY 1994}

Cost Estimate:

Engineering Design \& Inspection (1) 23.3\%

$\$ 480,000$

Construction Cost

$\$ 2,060,000$

1) Improvements to Land

2) Building Upgrades

3) Utilities, including the relocation of Steam, Condensate, Water \&

Waste Lines

4) Project/Construction Management $\$ 120,000$

Standard Equipment

Contingency at $18.3 \%$ of Above Cost

$\$ 620,000$

$\$ 1,280,000$

$\$ 40,000$

Total Project Estimate

$\$ 3,000,000$ 


\section{T-BUILDING LIFE SAFETY CODE UPGRADES \\ FY 1994}

Funding Profile:

Obligations

$\$ 350 \mathrm{~K}$

$\$ 2650 K$

0

0
Costs

$\$ 300 \mathrm{~K}$

$\$ 750 K$

$\$ 1730 \mathrm{~K}$

$\$ 220 K$ 


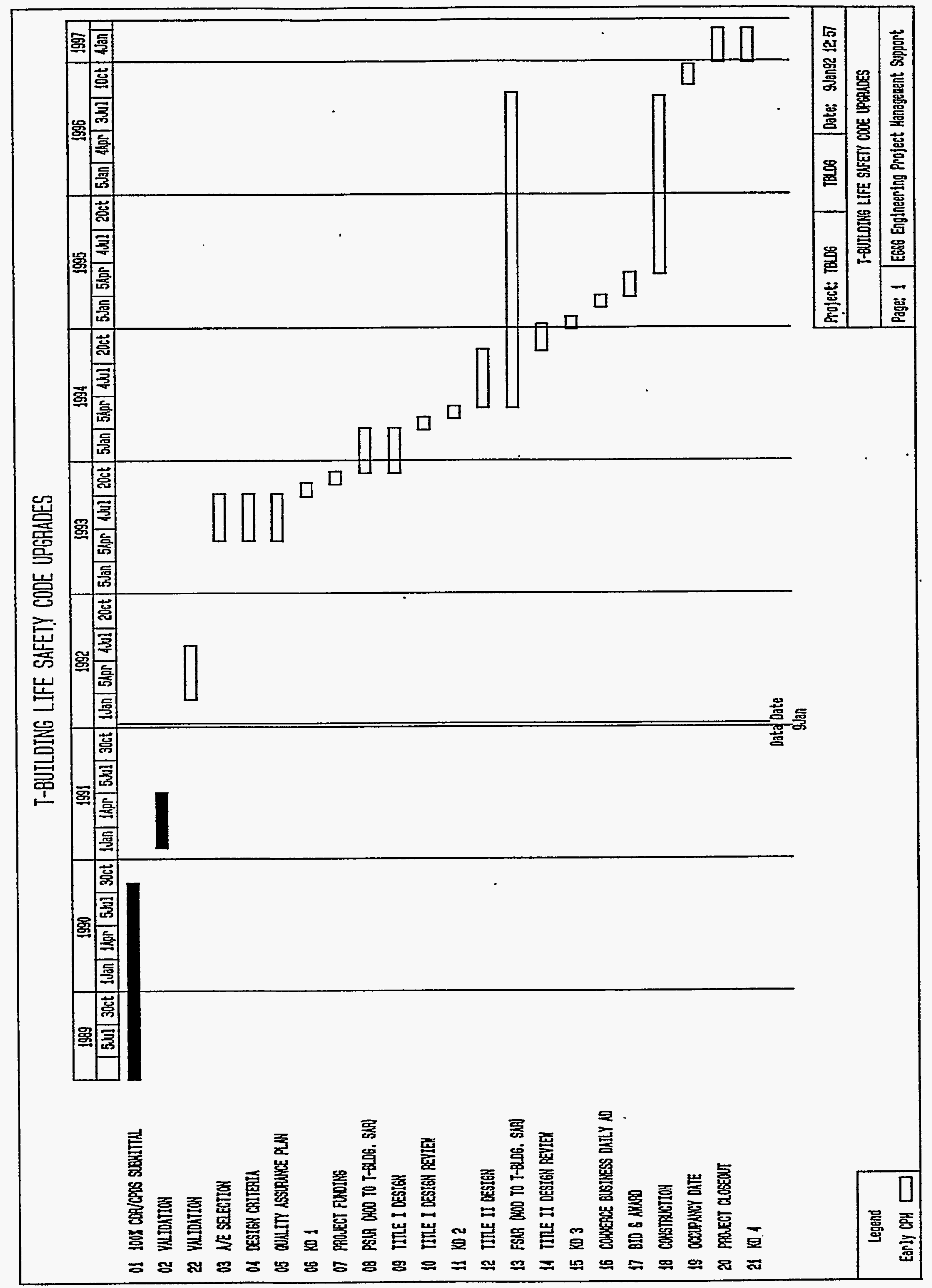




\section{ROADS AND PARKING LOT REPLACEMENTS FY 1994}

PROJECT NUMBER: 94-DA-03

PROJECT MANAGER: D. L. MORGAN

SPONSOR: R. E. BURDG

TEC: $\$ 2,200,000$ 


\section{ROADS AND PARKING LOT REPLACEMENTS}

\section{PROJECT DESCRIPTION}

The project will upgrade or replace eight sections of roadway and parking areas in the main hill area.

- Complete replacement of roadways

- Scarification, concrete joint repair and asphalt overlay

- Reconstruction of existing drainage structures

- Installation of new drainage structures

- Install new or replacement curbs

- Install new or: replacement sidewalks

- Install guardrails, signage and pavement markings 


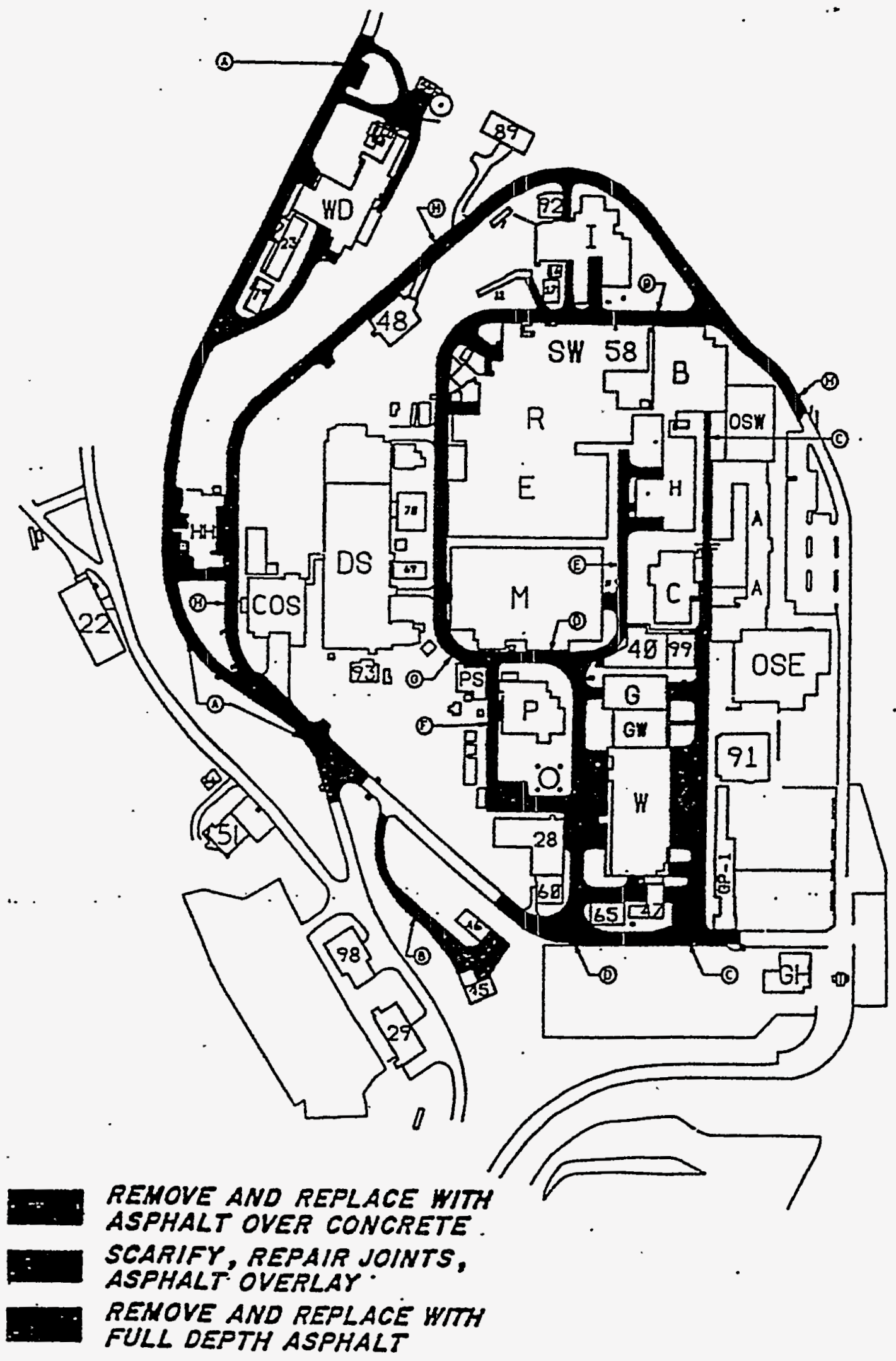

PROPOSED ROADHAY IMPROVEMENTS 


\section{ROADS AND PARKING LOT REPLACEMENTS}

\section{PROJECT DESCRIPTION}

Upon completion of construction activities, the project will have:

- Upgraded 3.50 miles of roadway

- Replaced or installed 68 drainage structures and 5,100 Ln. Ft. of drainage pipe

- Replaced or installed 14,820 Lf. of 6" concrete barrier curb

- Replaced or installed $3,750 \mathrm{Ln}$. Ft. of $5^{\prime}$ sidewalk

- Installed 650 Ln. Ft. of TYPE 5 guardrail

- Incorporated traffic signage \& pavement marking for traffic control and pedestrian safety 


\section{ROADS AND PARKING LOT REPLACEMENTS}

\section{JUSTIFICATION}

Reconstruct numerous segments of Mound's main hill road systems which have reached the end of their design life and are deteriorated beyond reasonable repair

- Correct the inadequate roadway drainage systems

- Support site drainage upgrades

- Correction of erosion control problems

- Provide capability to protect pedestrians from roadway traffic

- Correct tripping and slipping hazards

- Upgrade defective roadway structures

- Improve product and employee transportation

- Reduce vehicle maintenance costs 


\section{ROADS AND PARKING LOT REPLACEMENTS}

\section{DETAILS OF JUSTIFICATION}

Design will be in accordance with:

DOE Order 6430.1A - Division 1, 2 and 3

U.S. Department of Transportation "Handbook of Highway

Safety Design and Operating Practices."

Roadway Condition Analysis

1982 Bowser Morner Testing Laboratories Physical Condition Survey

78 Borings

Classification of existing roadway structures

Storm Drainage Analysis

Inadequate number of drainage structures

Failure of drainage structures (curbs, gutters, catch basins)

Erosion control - during and after construction

Pedestrian Safety Considerations

Sidewalks

Crosswalks

Signage. .

Handicap curbs 


\section{ROADS AND PARKING LOT REPLACEMENTS}

\section{IMPACT OF FUNDING DELAY}

Project Not Funded: ": Mound's main hill road systems would continue to deteriorate, ultimately impacting production, increasing safety hazards; and adversely.impacting the environment because of uncontrolled storm water run-off.

Partial Funding: $\quad$ Mound would prioritize the individual sections of road to be replaced. 


\section{MOUND PRIORITIZATION RATIONALE ROADS \& PARKING LOT REPLACEMENTS}

OVERALL RATING 52

HEALTH \& SAFETY - 50

- Industrial safety - minor injuries frequent

ENVIRONMENTAL/WASTE MANAGEMENT - 20

- N/A

SAFEGUARDS \& SECURTT - 40

- Best management practice - many minor concerns; potential problems in actual response situation

PROGRAMMATIC - 20

- Capacity - viable for mission 



\section{ROADS AND PARKING LOT REPLACEMENTS}

\section{FUNDING PROFILE*}

Obligations

FY 1994

FY 1995

FY 1996

700

1500

\section{$\$ K$}

Costs

920

800 


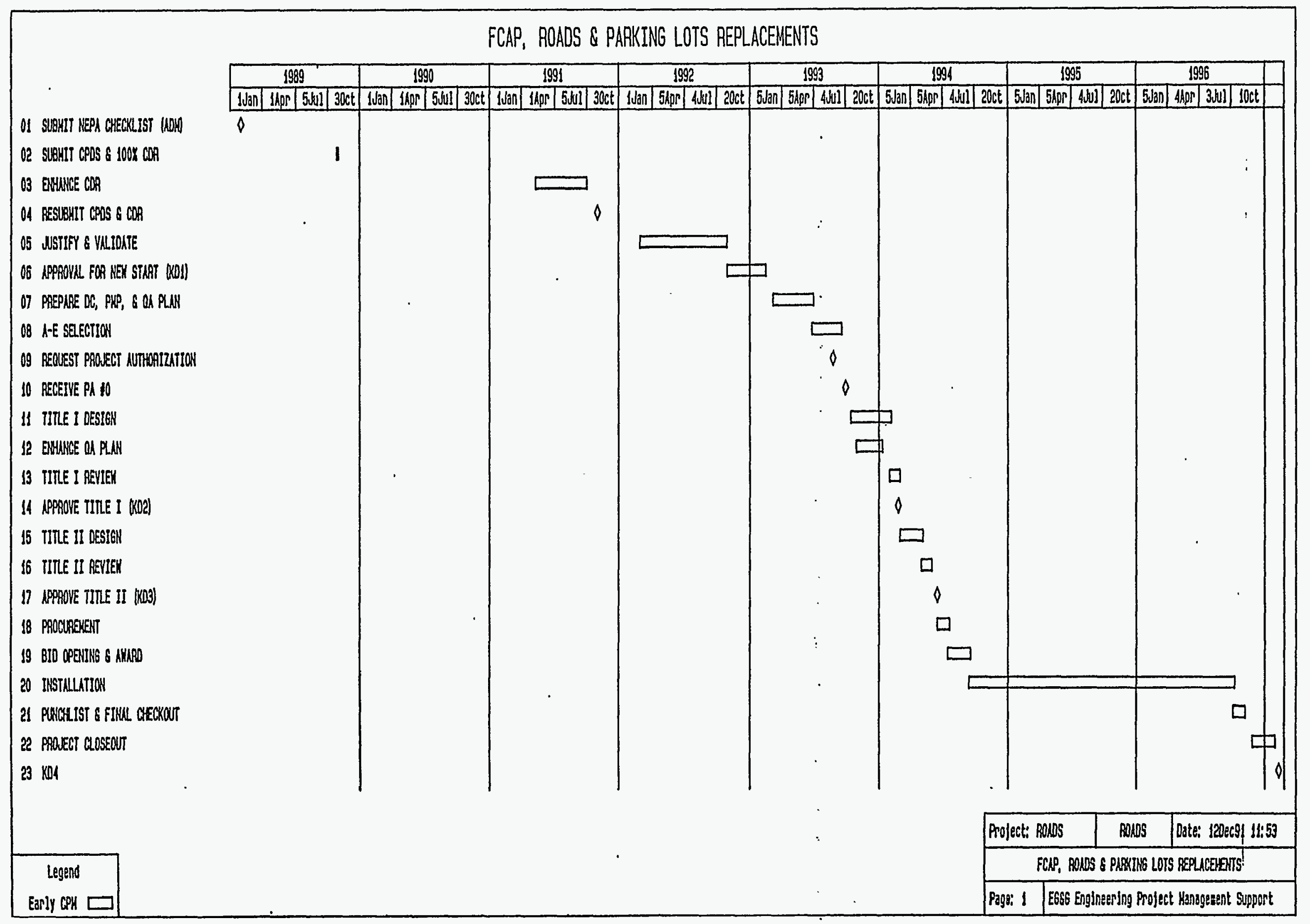



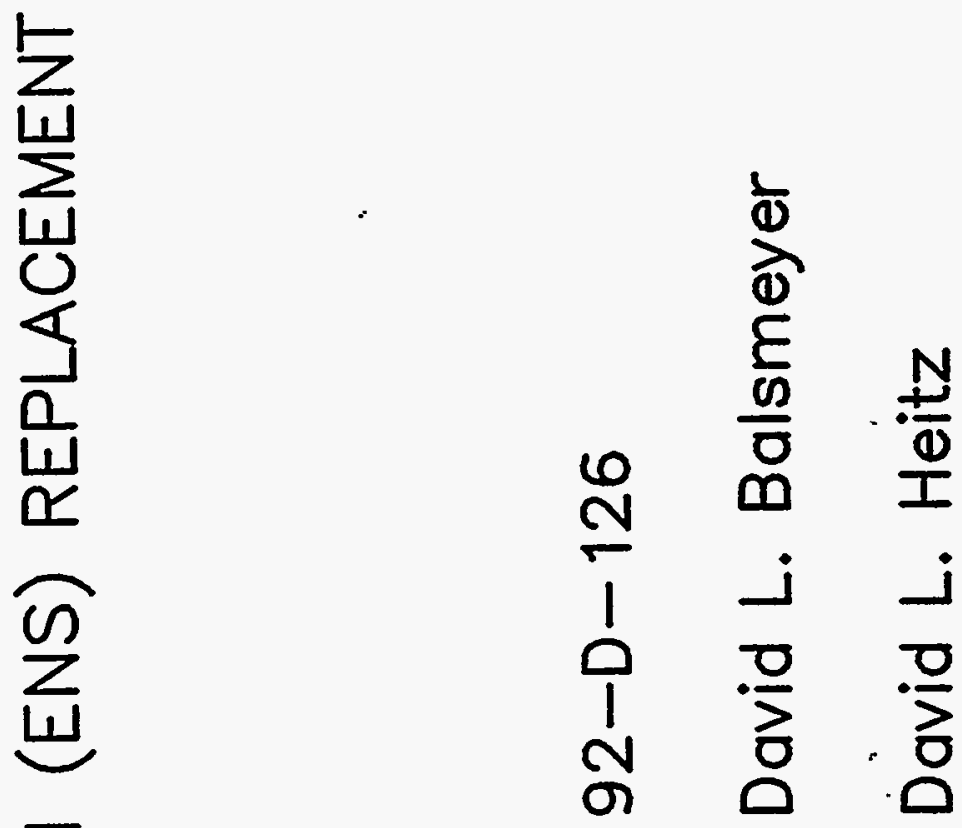

岕

$+$

$\because \frac{8}{2}$
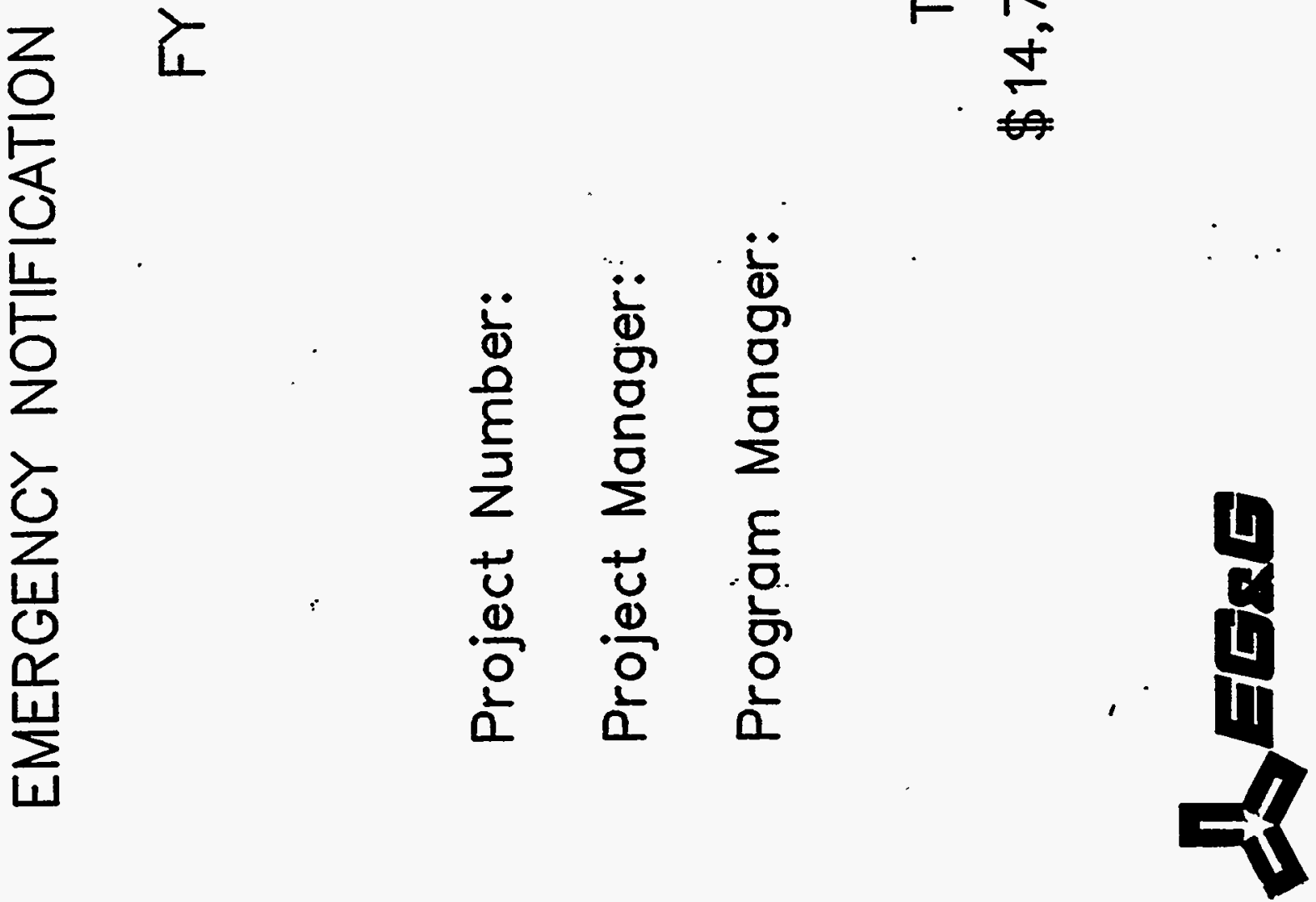


\section{ENS REPLACEMENT}

\section{PROJECT DESCRIPTION}

The PA and Fire Alarm systems will be integrated into one system.

The new PA system will: provide 2,643 speakers, 2,207 strobe lights and 127 amplifiers.

- The new system will be completely documented.

- The new system will be electrically supervised.

- Backup power will be provided.

- RF pagers will be provided for impaired hearing users.

Fire Alarm system will provide:

- Now central computers will be installed in Bldgs. 98, 99 \& 100.

- 41 command stations will be installed.

- Alarms will be sounded over the PA system.

- UL rated equipment will be used:

- Addressable Detectors will be located as code requires.

- Circuitry will be supervised.

- A 24. volt system will be installed.

Underground cabling will be reused for the PA and fire alarm upgrades. Radio system - 5 channel trunked system replaces 13 existing systems. 


\section{ENS REPLACEMENT}

\section{JUSTIFICATION:}

PA system must be replaced to inform all personnel of emergencies. The current general paging system is obsolete and undocumented.

- The new system must meet NFPA, DOE \& OSHA.

- The new system must be electrically supervised.

- System audio must be heard throughout the plant.

Fire Alarm system needs to be upgraded to add capability \& reliability.

- The new system must meet NFPA, DOE \&C OSHA.

- Primary and back-up central data collection and alarm computers are needed.

- Command stations are needed at critical areas.

Radio system will provide improved communications among users. During emergencies, communications among response groups are unreliable and in some cases non-existent. 
$\frac{0}{0}$

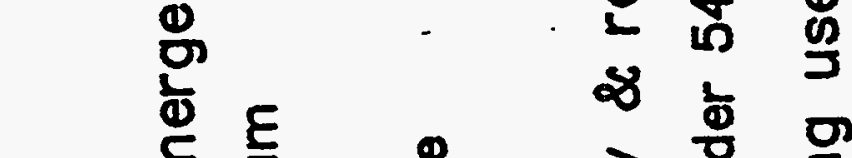

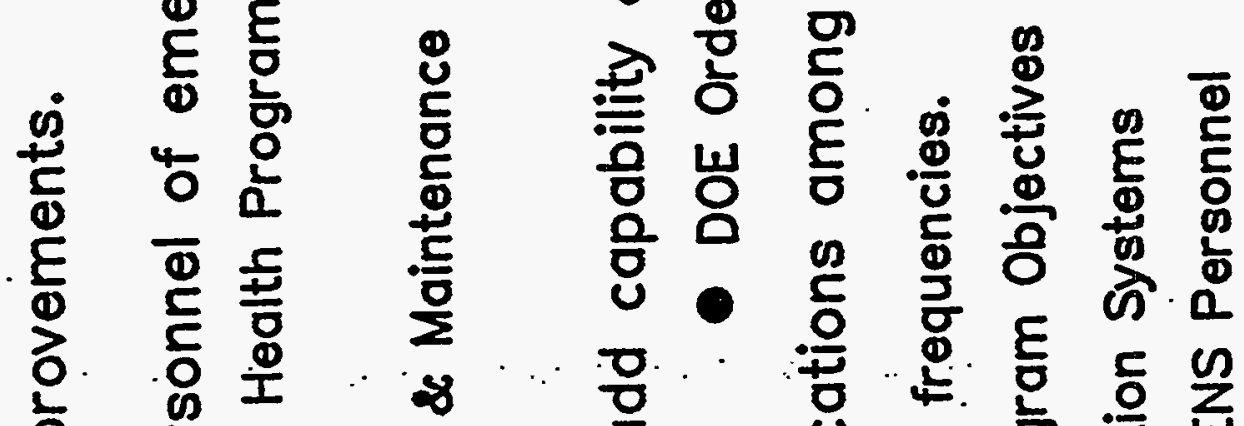

흘

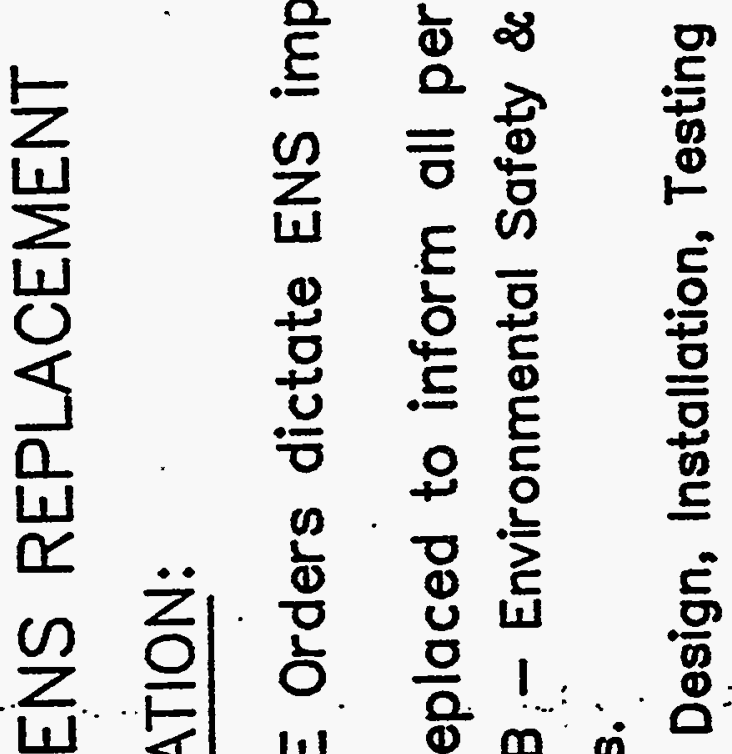

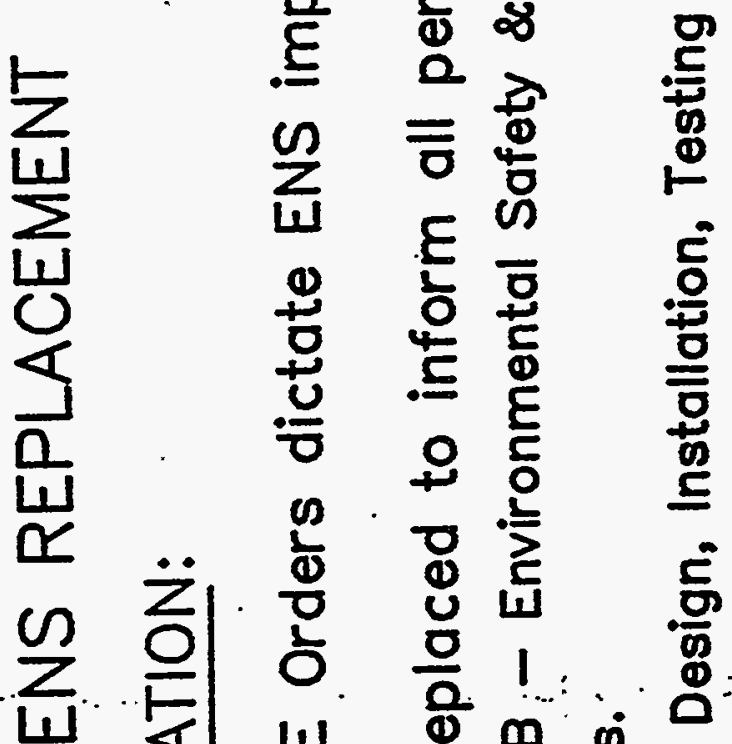

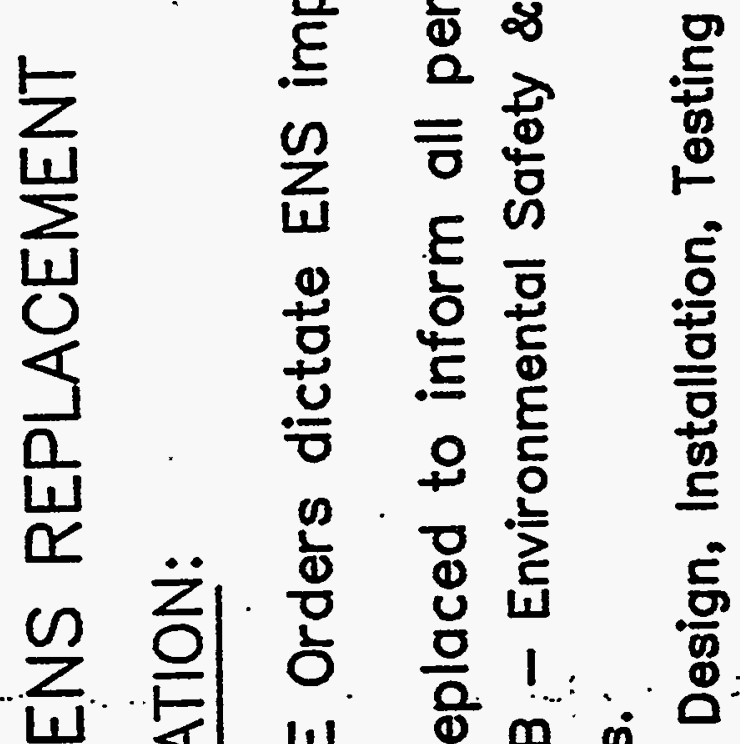

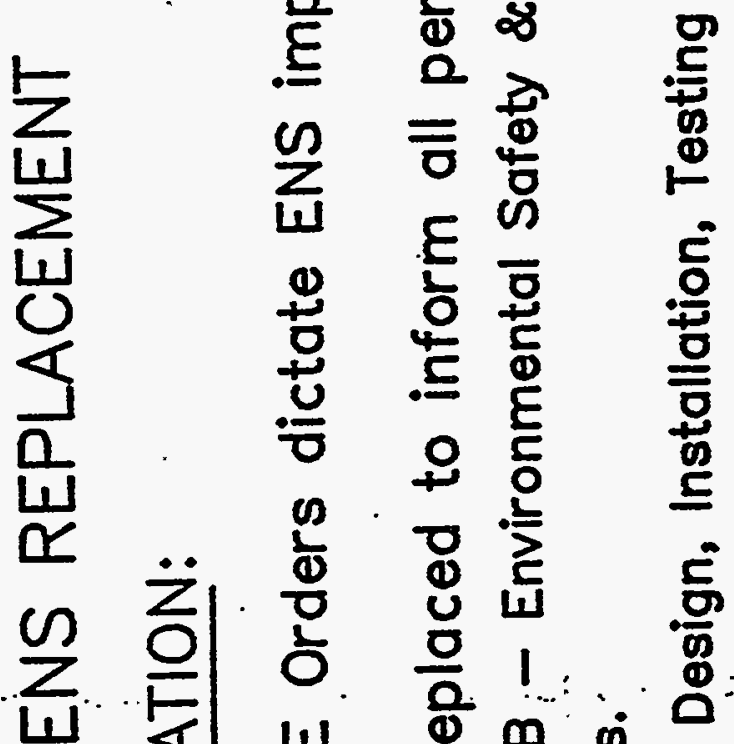

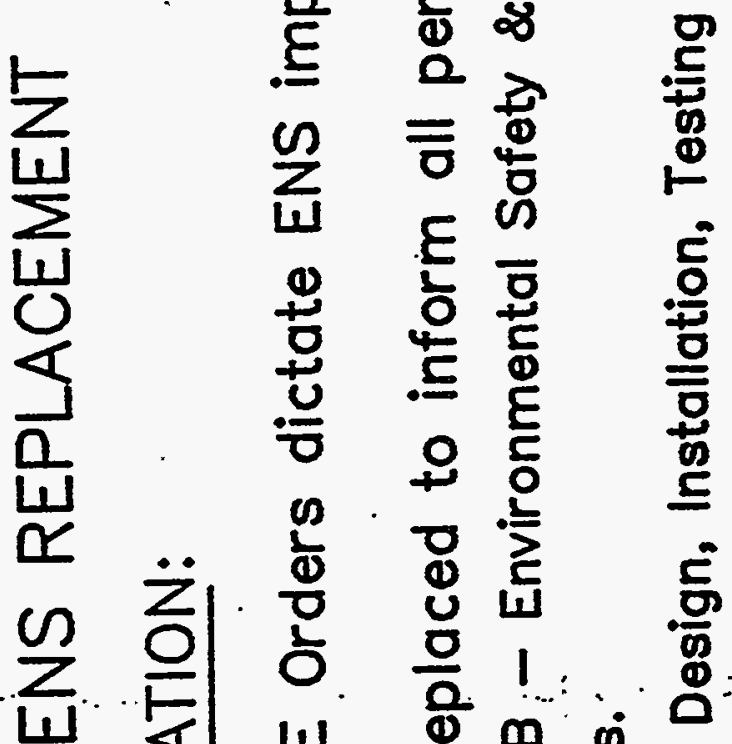

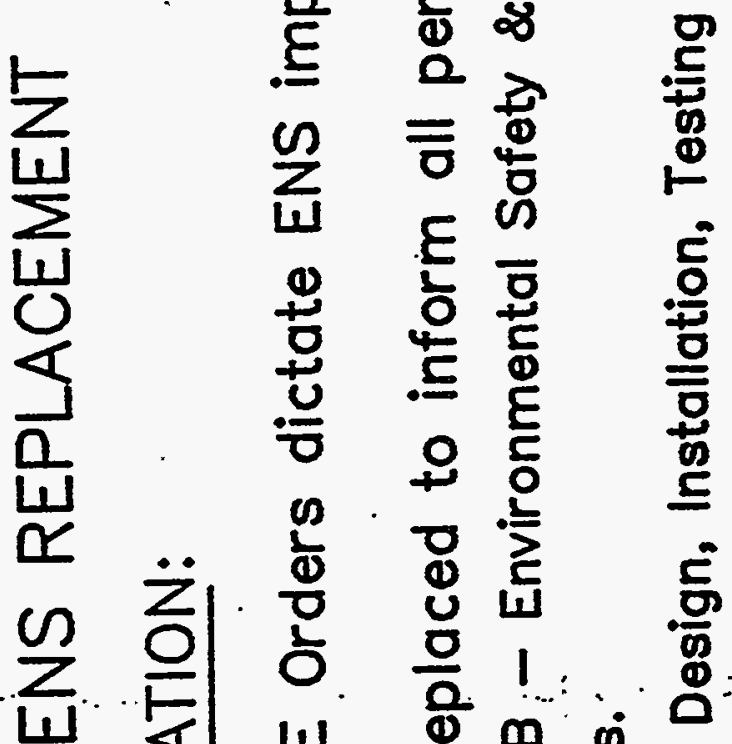

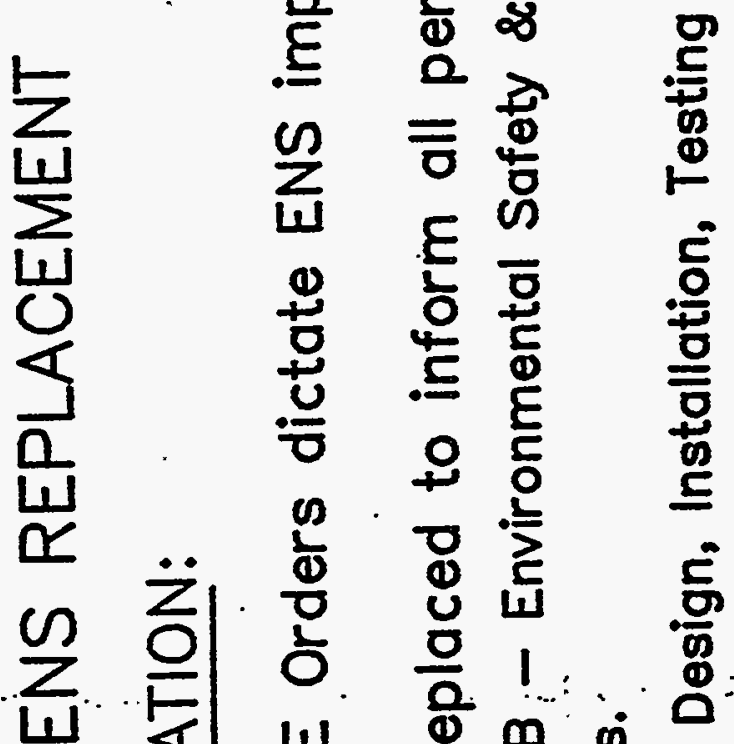

离

声

声

$引$

ᄂ

a

光

5 $\sum_{4}^{\infty}$

w

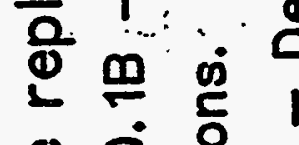

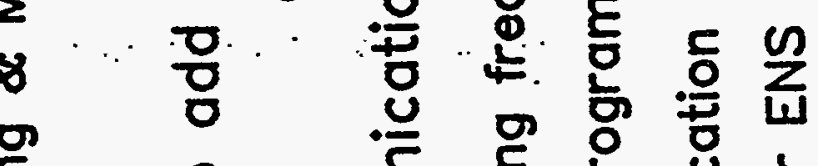

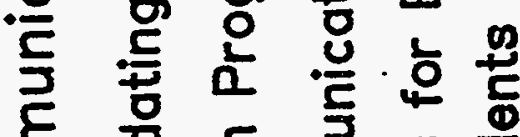

$\stackrel{\bullet}{\llcorner}$

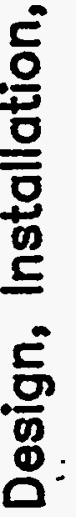

它

ชั่ง

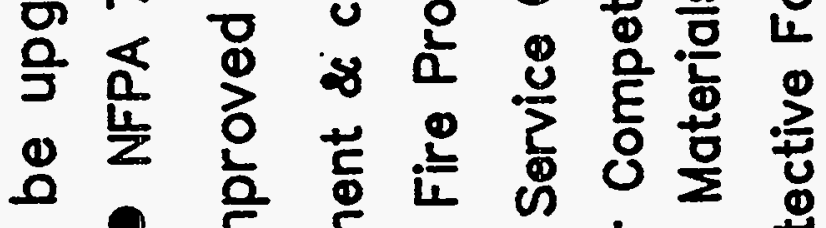

○ E E 山ل

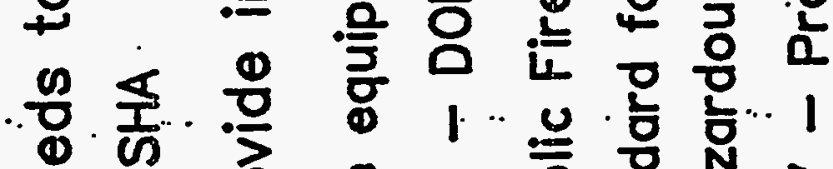

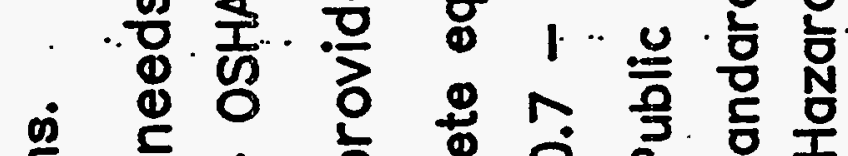

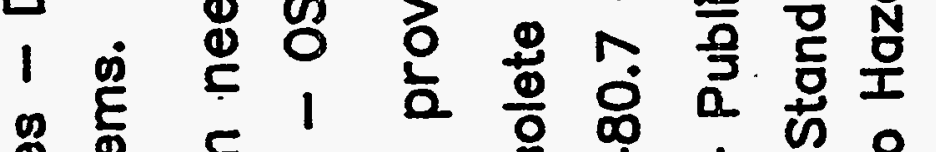

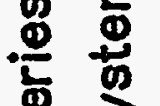

$E 0=$ 要 1 क

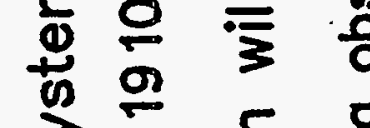

दे。

\& $E$ क्षे $N E$ के

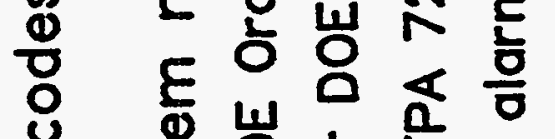

番 岁

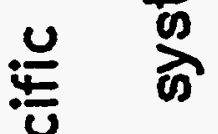

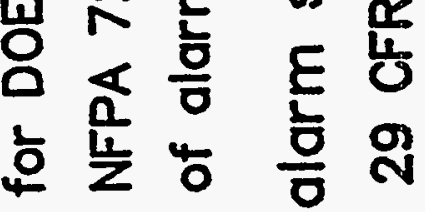

ㄴ. 은

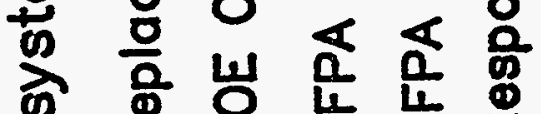

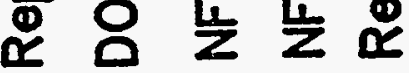

E

8 옹

ปิ่

嵓

迺

ย ㅎํㅎำ

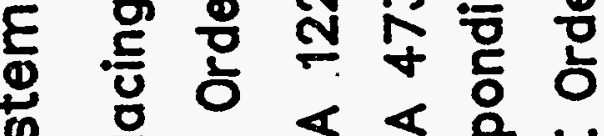

岁

口 


\section{ENS REPLACEMENT}

Other Considerations:

- Security Considerations included in the ENS project.

- Signal encryption will be evaluated during design.

- MECS cabling will be modified for ENS signal transmissions.

- DOE Order 5636.3A, Tech. Surveillance Countermeasures, impacts will be minimized.

- Tiger Team 1989 finding \#EP/CF-1 for improved Personnel Accountability will not be implemented with the ENS project.

- Quality Assurance is Levels II \& III for the ENS project.

- Energy efficient equipment will be used as it is available.

- Project paybacks are not applicable to the ENS project.

- Five AL sites are coordinating ENS needs in this Line Item. Mound, ORNL $Y-12$, Pinellas, Pantex \& KC are included. 


\section{ENS REPLACEMENT}

Impacts of Funding Delays:

- Existing outdated emergency notification equipment will

- be subject to breakdown

- require increasing maintanence.

- not provide the needed level of safety.

- Personnel safety will be compromised.

- Mound's PA, fire alarm, and radio systems will not meet NFPA, DOE and OSHA regulations. 


\section{MOUND PRIORITIZATION RATIONALE EMERGENCY NOTIFICATION SYSTEM REPLACEMENT}

OVERALL RATING 58

HEALTH \& SAFETY - 55

- Regulatory compliance - frequently in compliance, but serious violations are possible (NFPA 72)

- Fire protection - fire department response

ENVIRONMENTAL/WASTE MANAGEMENT - 30

- Best management practice - many minor concerns (alarms)

SAFEGUARDS \& SECURITY - 45

- Best management practice - some significant concerns response time

PROGRAMMATIC - 20

- $N / A$ 


\section{ENS REPLACEMENT}

Cost Estimate $(10 / 22 / 91)$

Engineering, Design and Inspection

at approx. $18 \%$ of construction cost

$\$ 1,900,000$

Construction Cost

$10,700,000$

Special Facilities

Emergency PA

Radio

$4,650,000$

Fire Alarm

Construction Management

$3,500,000$

$2,100,000$

Project Management

200,000

250,000

Contingency at approx. $17 \%$ of above costs

$2,100,000$

Total Project Estimate

$\$ 14,700,000$ 


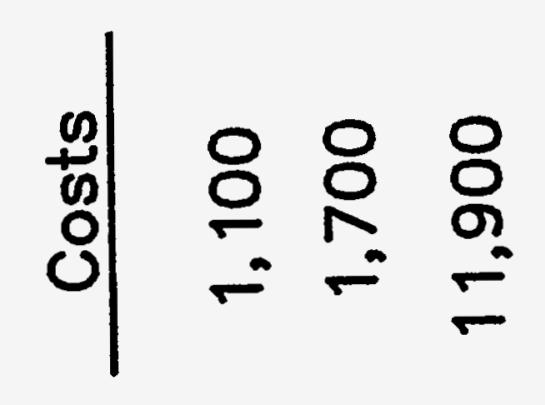

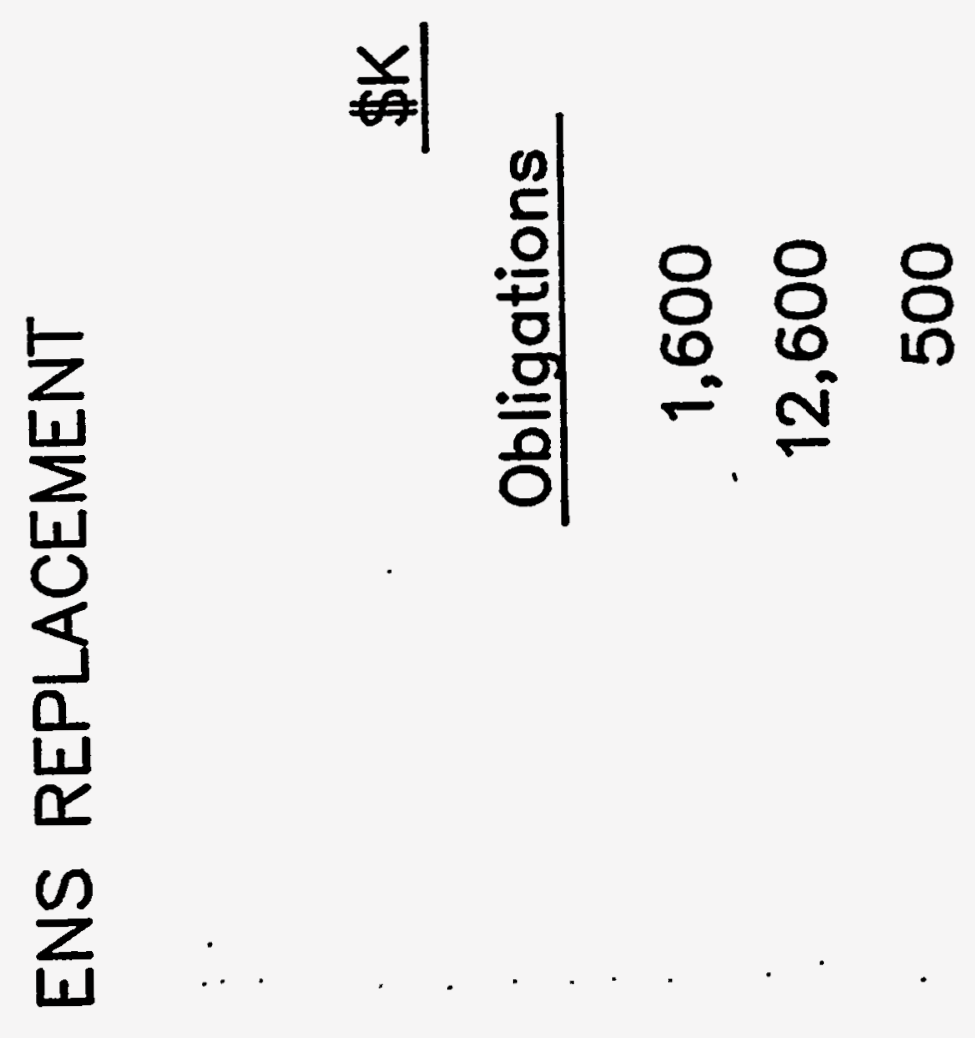

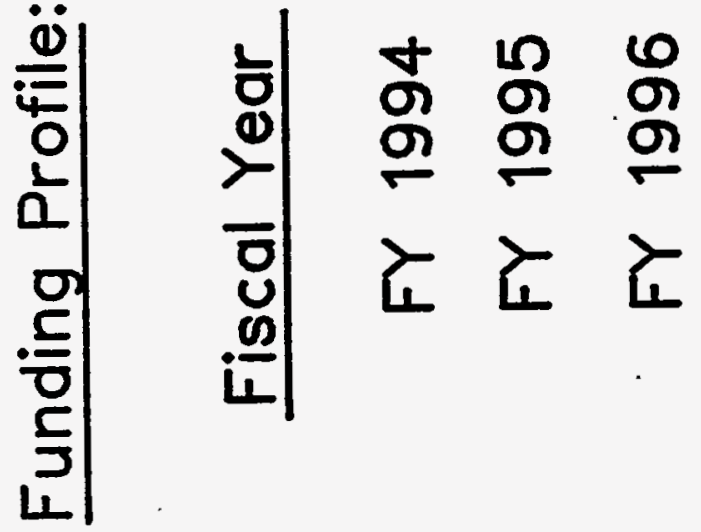




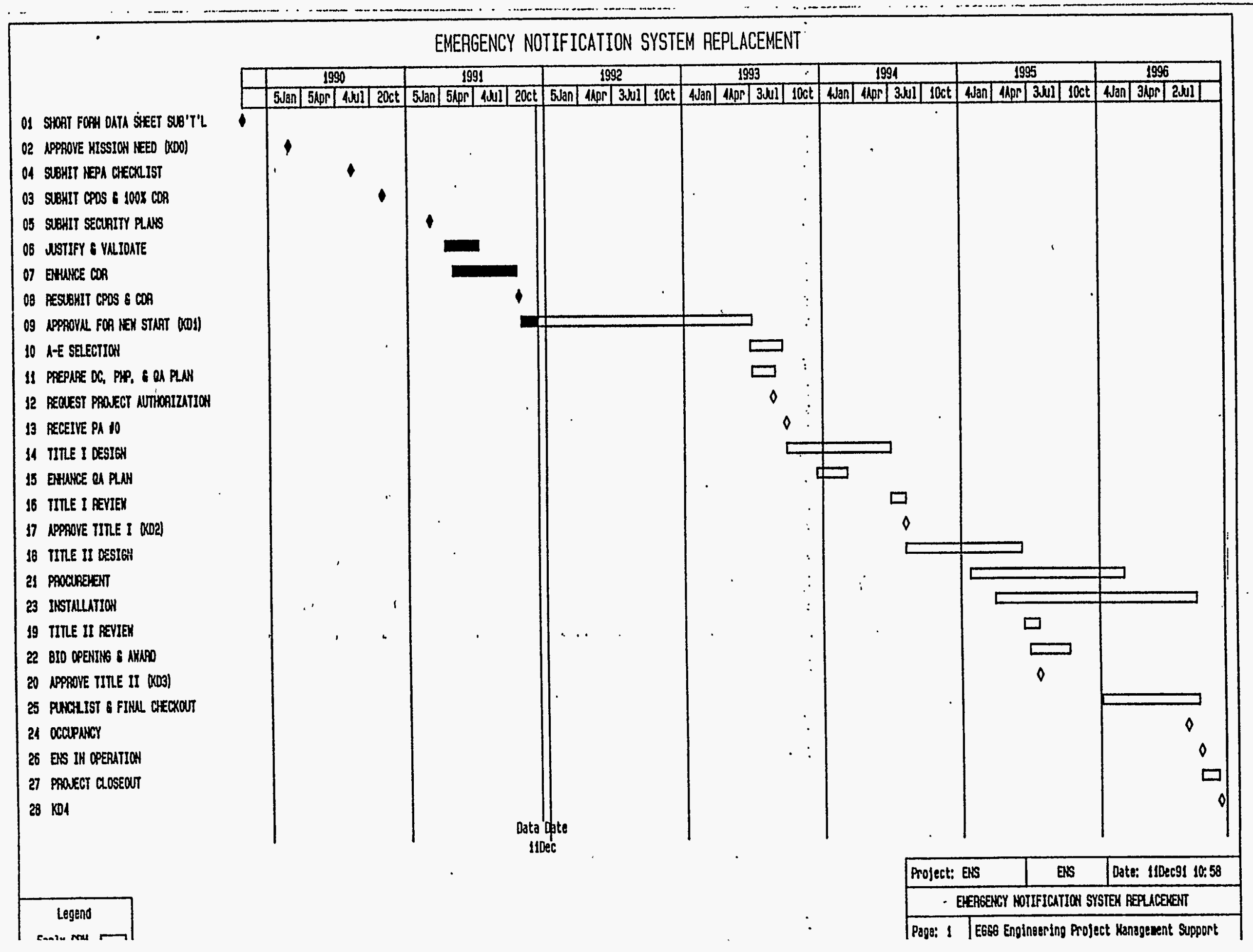



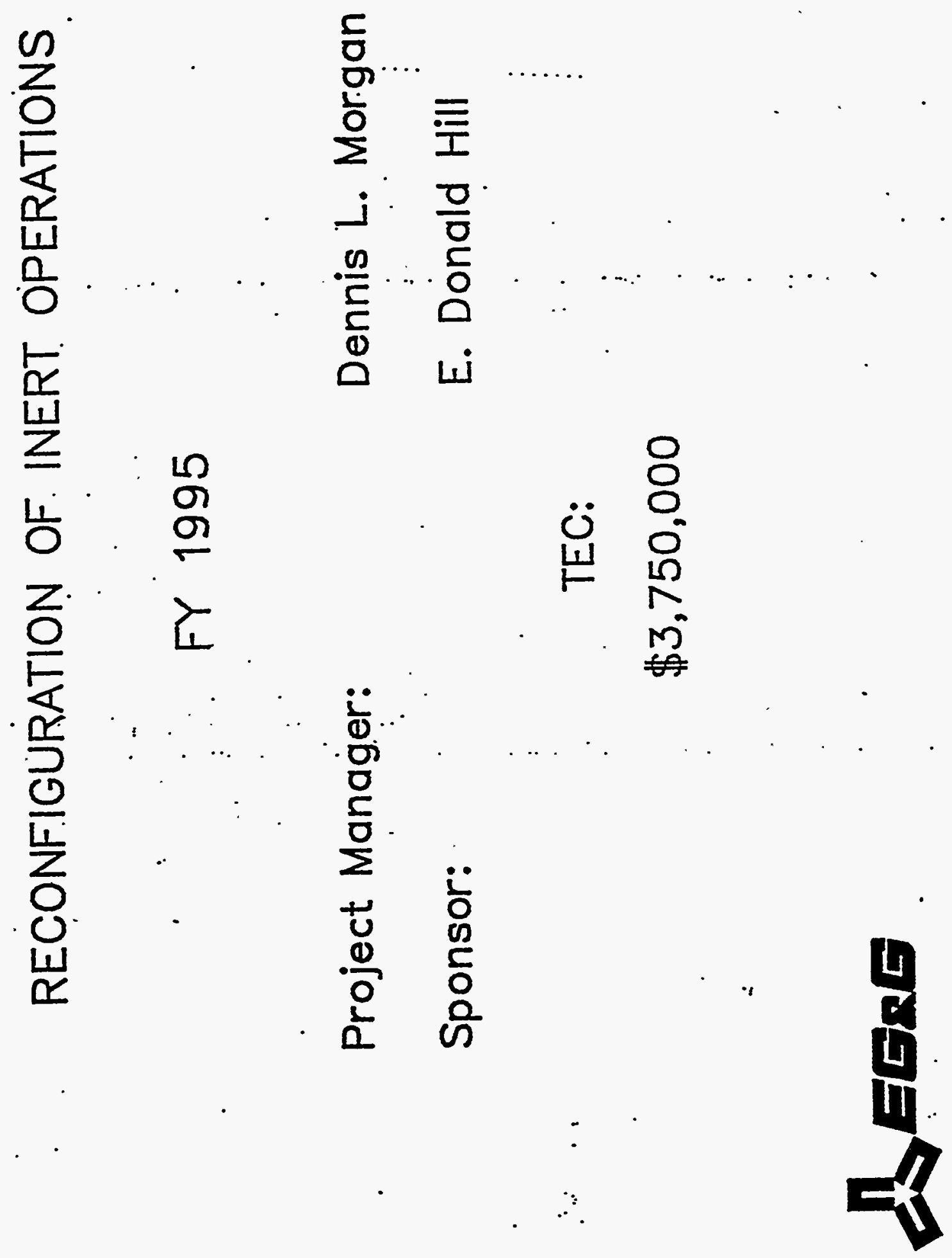


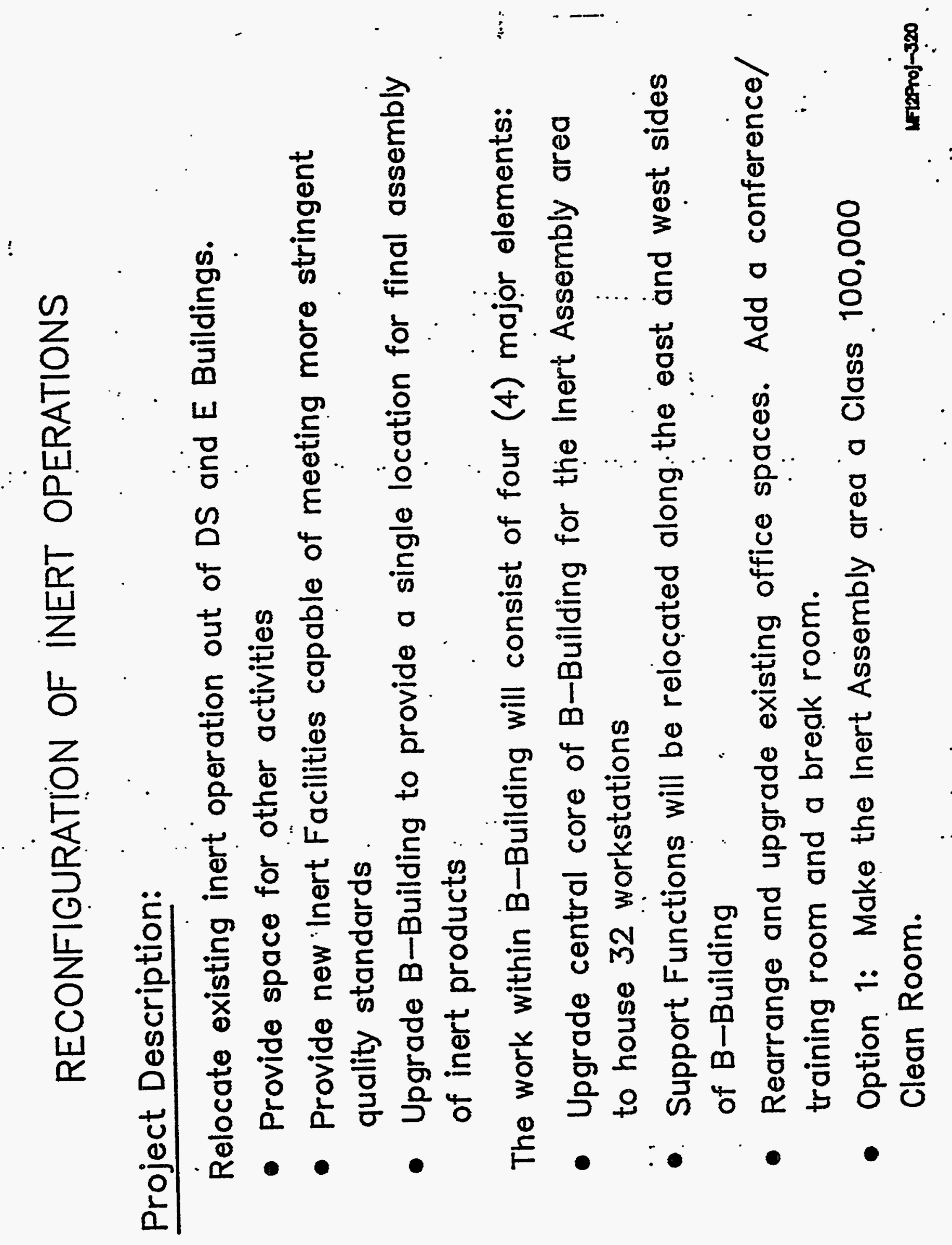




\section{RECONFIGURATION OF INERT OPERATIONS}

Justification:

- Existing manufacturing facilities have been appraised and determined to be in poor condition and technologically inadequate.

- Existing fragmented manufacturing space requires many products to be transported through several buildings during the manufacturing process.

- Existing facilities cannot provide the clean atmosphere and effective temperature and humidity controls necessary for smaller and more intricate production designs. 


\section{RECONFIGURATION OF INERT OPERATIONS}

Details of Justification:

- Reconfiguration allows more effective use of space by utilizing Group Technology Concepts in the layout of production processes.

- Manufacturing operations will be more cost effective

- Less travel time for both material and personnel

- Reduced Work-in-Process inventory required

- Reduced downtime costs-ability to easily transfer personnel

- Less direct supervision required--proximity of work force

- Reduce cost of quality control

- Ease of use of Continuous Flow Manufacturing techniques 


\section{MOUND PRIORITIZATION RATIONALE RECONFIGURATION OF INERT OPERATIONS}

HEALTH \& SAFETY - 20

- Industrial safety - few concerns with occasional minor incidents

ENVIRONMENTAL/WASTE MANAGEMENT - 20

- Waste minimization - process generates relatively little waste

SAFEGUARDS \& SECURITY - 45

- Technological base - develops new methodologies to improve/ enhance safeguards and security capability and efficiency

PROGRAMMATIC - 50

- Technological base - develops new methodologies to improve/ enhance mission capability and efficiency. 


\section{RECONFIGURATION OF INERT OPERATIONS}

Cost Breakdown:

A. ED\&1@ $17.5 \%$

B. Construction

1. Asbestos Removal

2. Building Upgrades

3. Utilities

4. Project Mariagement

5. Construction Management

6. Option 1

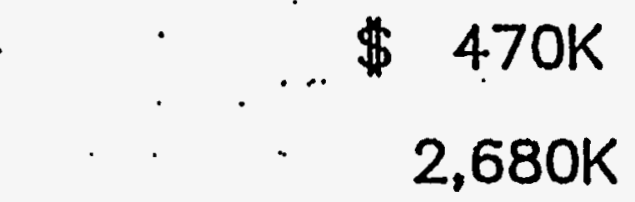

$90 \mathrm{~K}$

$1,920 \mathrm{~K}$

OK

$220 \mathrm{~K}$

$180 \mathrm{~K}$

$270 \mathrm{~K}$

C. Contingency @ $19.0 \%$

TOTAL 


\section{RECONFIGURATION OF INERT OPERATIONS}

Funding Profile:

FY 1995

Obligations

Costs

$\$ 500 \mathrm{~K}$

$\$ 450 \mathrm{~K}$

FY 1996

$\$ 3250 \mathrm{~K}$

$\$ 2200 \mathrm{~K}$

FY 1997

0

$\$ 1100 \mathrm{~K}$ 


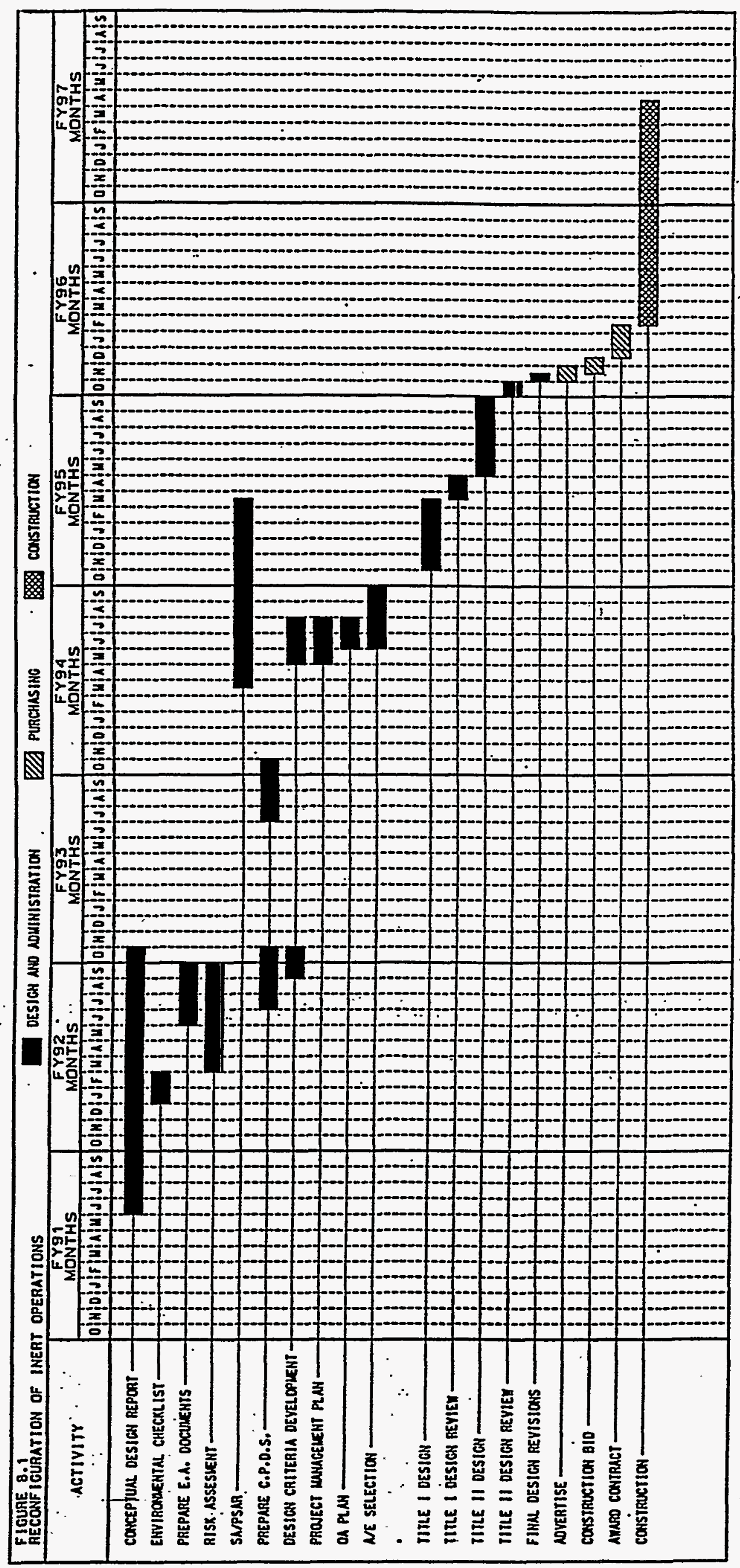




\title{
STEAM AND CONDENSATE SYSTEMS UPGRADES
}

\author{
FY 1995
}

Project Number:

Project Manager:

88D-122(95-XX)

Project Sponsor:

\section{Richard L. Bauer}

Larraine A. Kapka

TEC:

$\$ 7,000,000$ 


\section{STEAM. AND CONDENSATE SYSTEMS UPGRADES}

\section{Project Description:}

Continuous and reliable steam service will be achieved by:

- Increasing installed steam generating capacity.

- Replacement of undersized and deteriorated steam and condensate piping

- Replacement of deteriorated piping insulation 


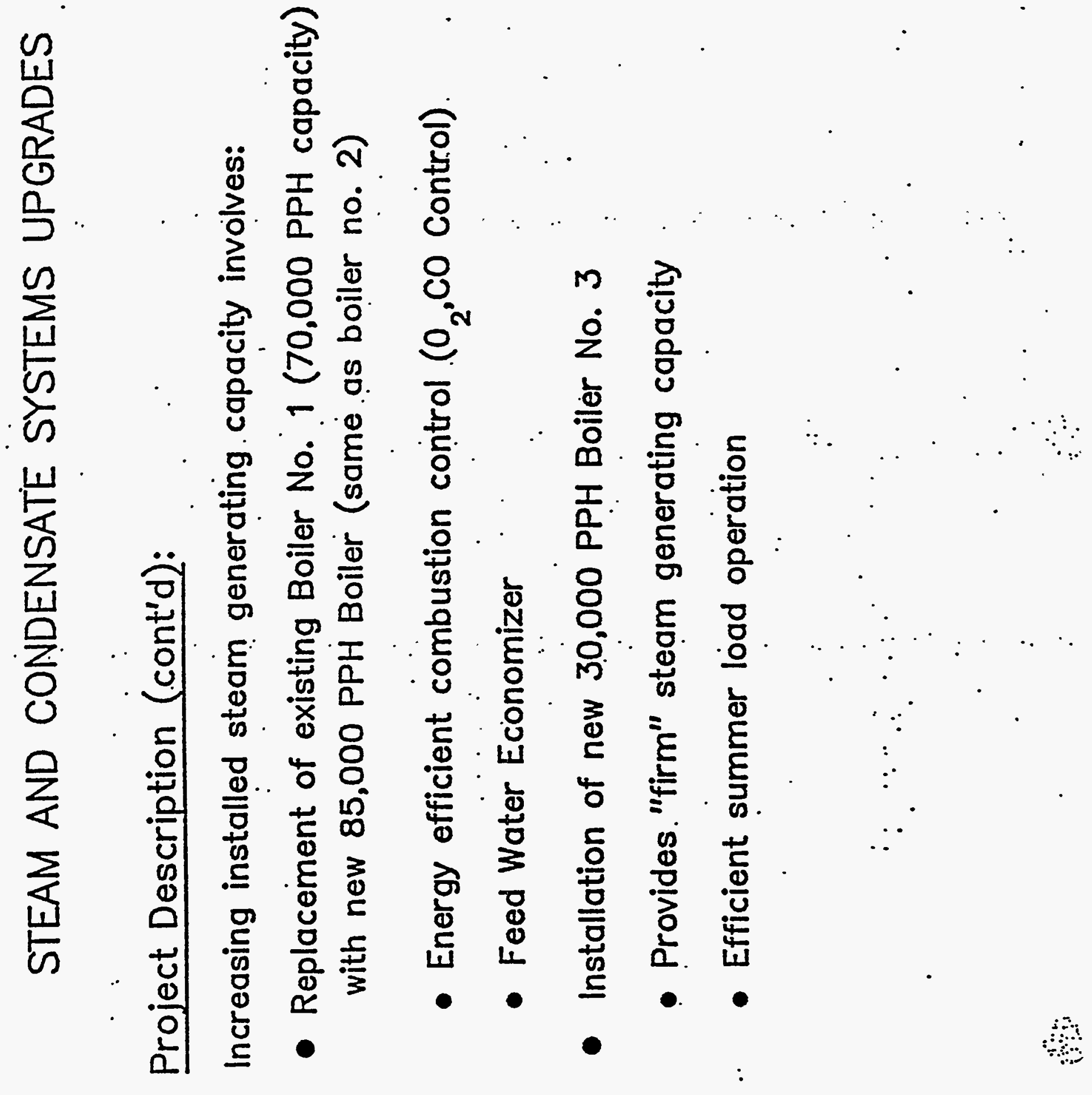




\section{STEAM AND CONDENSATE SYSTEMS UPGRADES}

\section{Project Description (cont'd):}

Increasing installed steam generating capacity involves:

- Construction of 2600 s.f.' Building Addition

- Necessary to accommodate boilers

- Relocation and expansion of Control Room 
$\therefore$
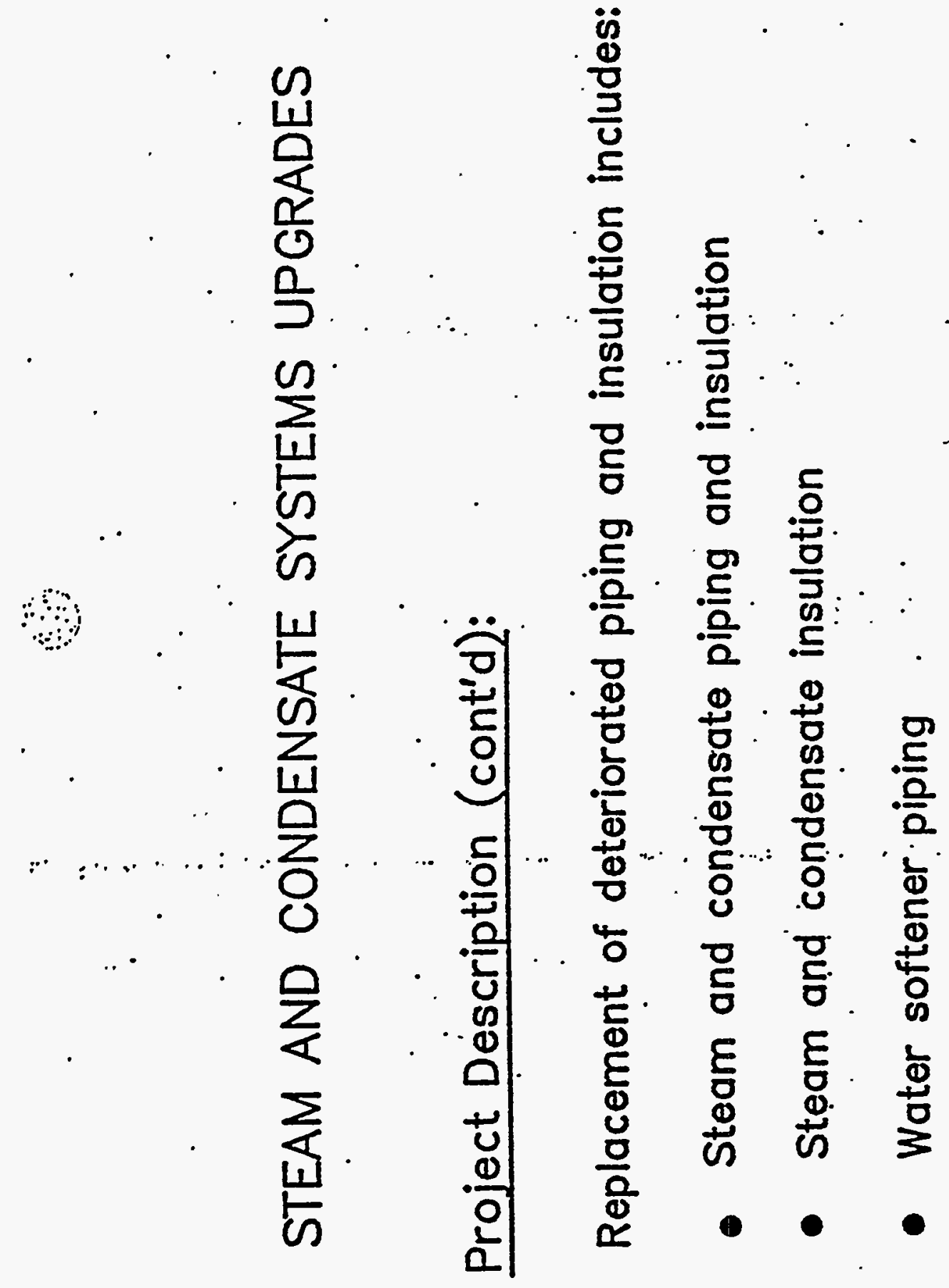

.

.

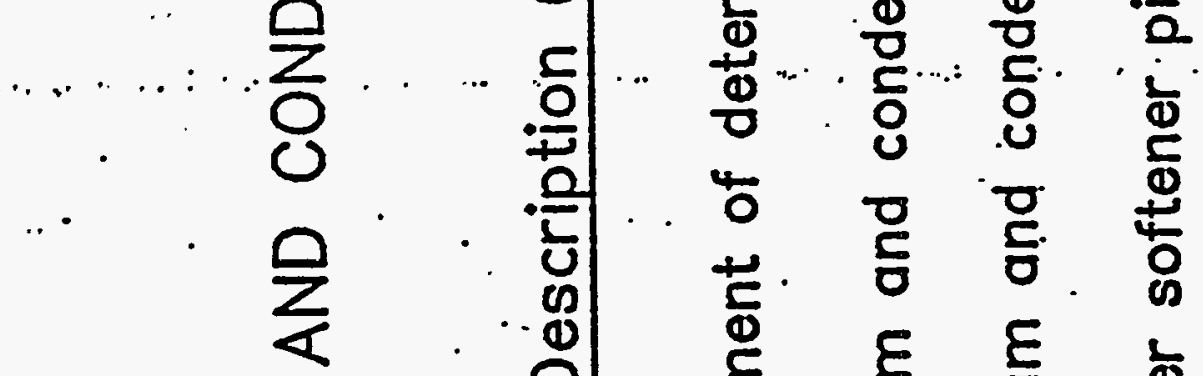

$$
\begin{aligned}
& \text { 总救 } \\
& \text { 总 } \frac{E}{\mathrm{~g}}
\end{aligned}
$$




\section{STEAM AND CONDENSATE SYSTEMS UPGRADES}

\section{Justification:}

- Non-Compliance to DOE Order 6430.1A

- Requirement for a continuous and reliable steam generation and distribution system serving the plant site

- Increased Square Footage since 1983

- Deteriorated Equipment, Piping and Insulation 


\section{STEAM AND CONDENSATE SYSTEMS UPGRADES}

Details of Justification:

- DOE Order 6430.1A Section 1555-1.2 requires:

"Sufficient capacity shall be furnished to permit one boiler to be down for inspection maintenance, or on standby, while the boiler(s) maintain normal operations." 


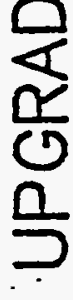

우

0

$\sum_{i=1}^{\infty}$

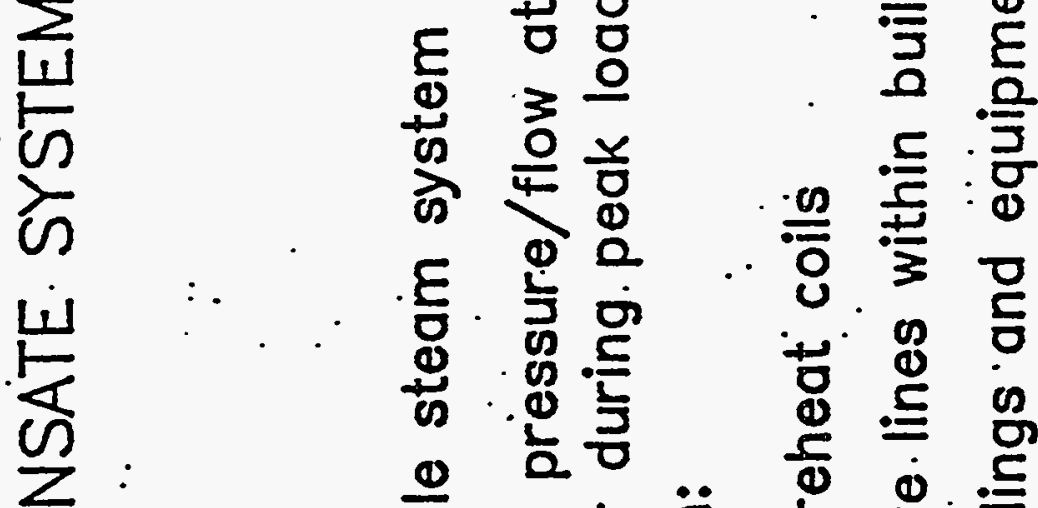

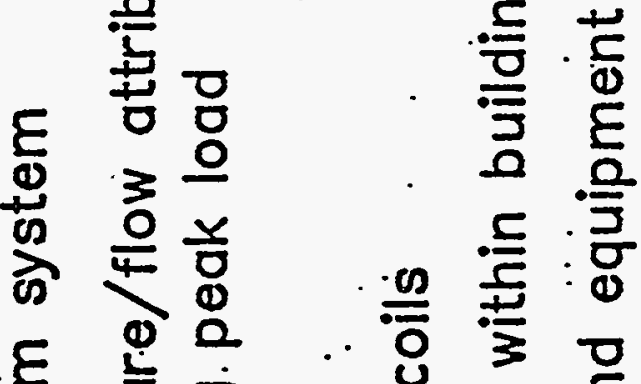

प्

ज

岩

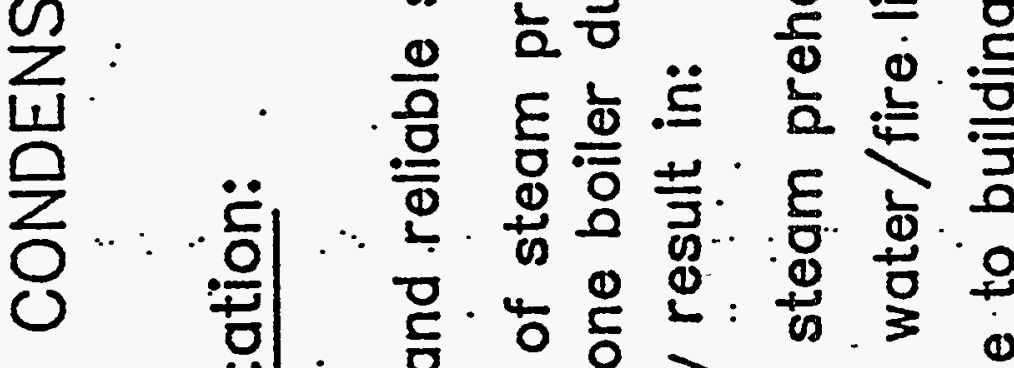

是

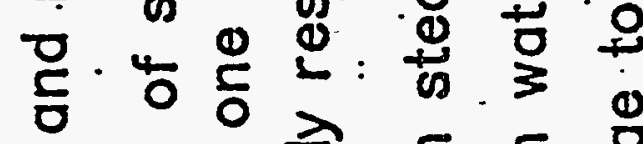

里

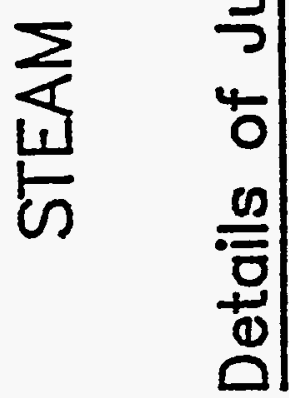

ठ

. 


\section{STEAM AND CONDENSATE SYSTEMS UPGRADES.}

\section{Details of Justification:}

- Increased Square Footage Since 1983

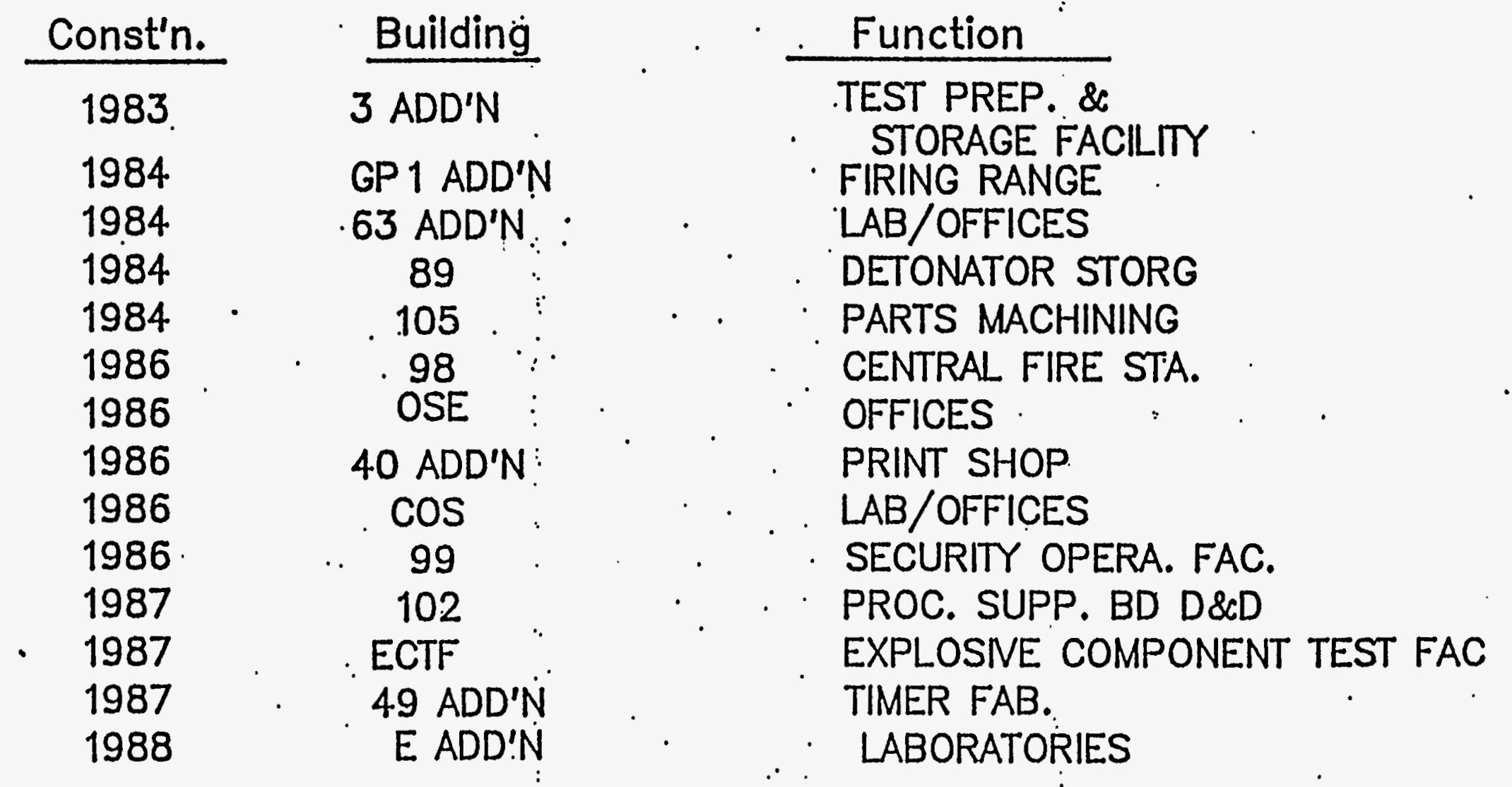

Total Add'I SF, of 280,000 . 


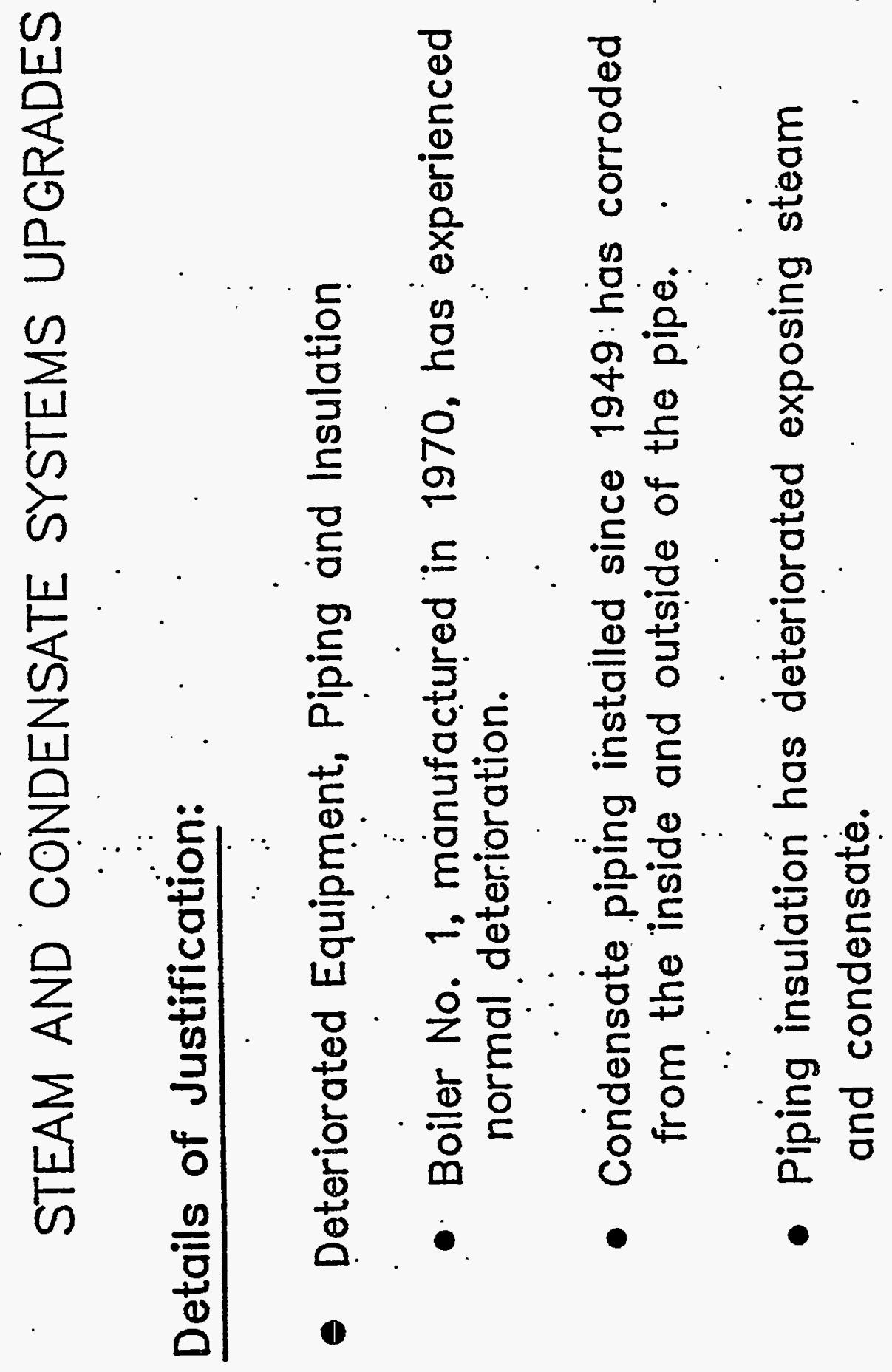




\section{STEAM \& CONDENSATE SYSTEMS UPGRADES}

Impacts of Funding Delays:

- Operate the site without firm steam capacity and risk operational impact to production buildings

$T, 50, R, S W, 38$ \& $H H$

Potential catastrophic building dämage

- Continue to repair equipment and piping as it fails 


\section{MOUND PRIORITIZATION RATIONALE STEAM \& CONDENSATE SYSTEMS UPGRADES}

OVERALL RATING $\quad 51.5$

HEALTH \& SAFETY - 35

- Best management practice - minor safety concerns

ENVIRONMENTAL/WASTE MANAGEMENT - 20

- Consistently in compliance; any violations extremely unlikely

SAFEGUARDS \& SECURITY - 20

- N/A

PROGRAMMATIC - 50

- Compliance with orders - redundant capacity unavailable

- Physical condition - poor, operation/mission threatened 


\section{STEAM AND CONDENSATE SYSTEMS UPGRADES}

\section{Cost Estimate}

Engineering, Design and Inspection

$\$ 790,000$ at approx. $15 \%$ of construction cost Construction Cost

Building

Boilers

Instrumentation

Utilities

Project Management

Contingency at approx. $17 \%$ of above cost

Total Project Estimate

$$
\begin{array}{r}
600,000 \\
1,350,000 \\
600,000 \\
2,460,000 \\
200,000
\end{array}
$$

$1,000,000$

$\$ 7,000,000$ 

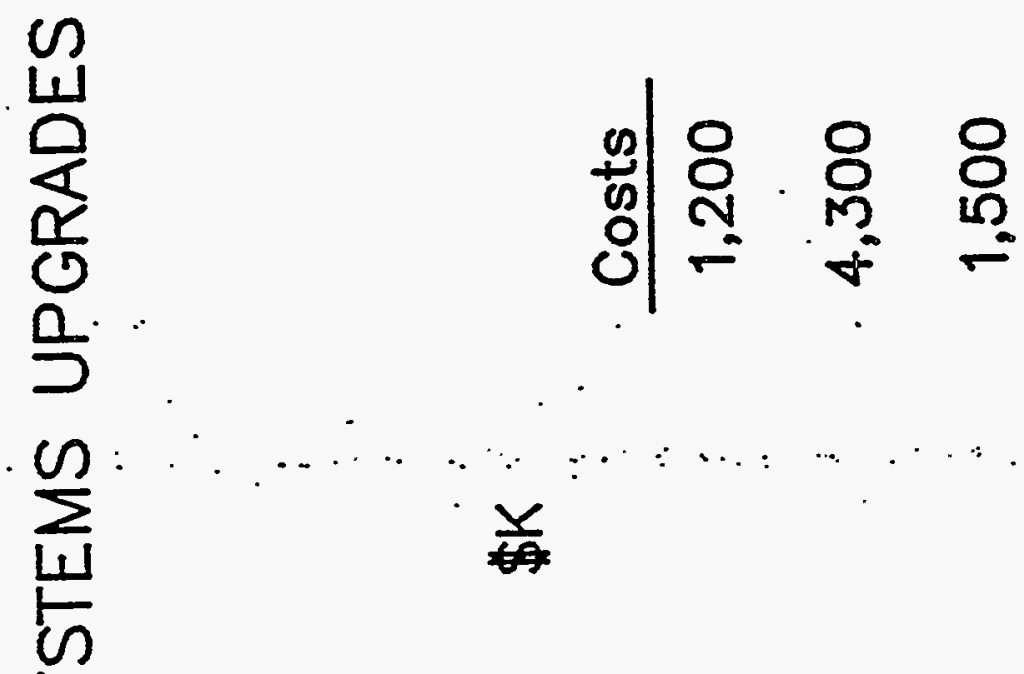

$\frac{1}{t=2}$

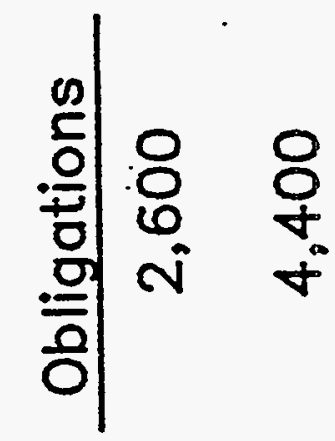

$\sum_{4}^{4}$

Z

0

$\$$

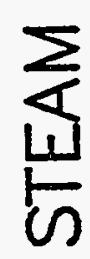

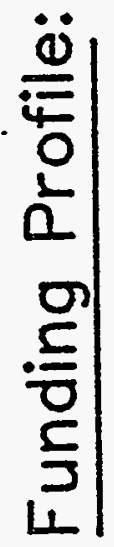

$\begin{array}{lll}\text { in } & 0 & N \\ \text { o } & \sigma & \sigma\end{array}$

乙石 


\title{
SITE DRAINAGE CONTROL
}

\author{
FY 1995 \\ Project Manager: Duane L. Woods \\ Project Sponsor: Charles S. Friedman
}

TEC: $\$ 17,300,000$ 


\section{- SITE DRAINAGE CONTROL}

\section{Project Description:}

Eliminate uncontrolled stormwater leaving site.

- Stormwater leaves the site unsampled and uncontained from three significant areas of the developed portion of the site.

- Curbs, berms, and culvert piping will be installed to collect and redirect stormwater to where it may be monitored and sampled. 


\section{SITE DRAINAGE CONTROL}

\section{Project Description:}

Upgrade stormwater surface control management system.

- Storm sewers, curbs, and channels will be installed to reduce stormwater flow over unpaved areas. 


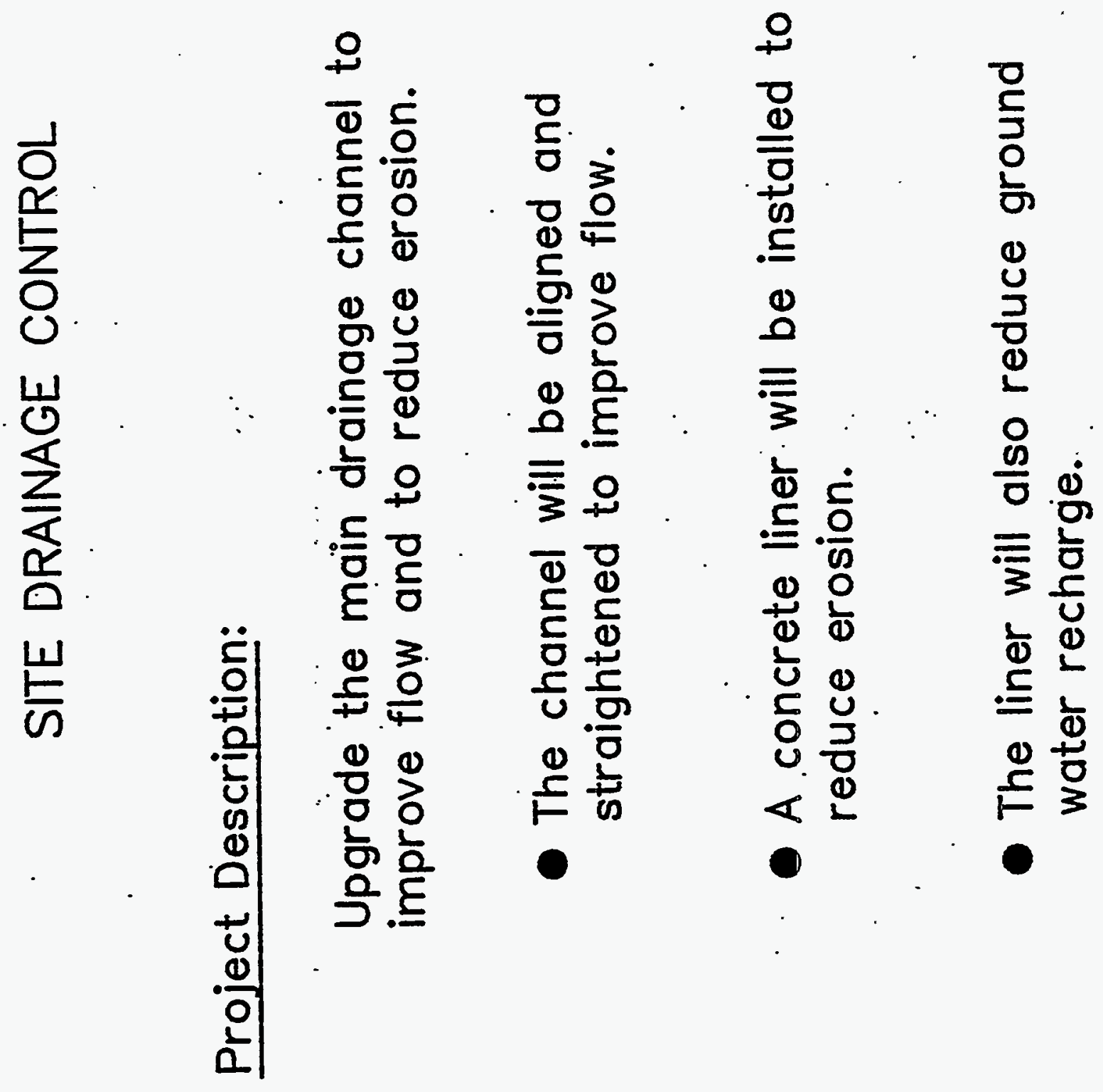




\section{SITE DRAINAGE CONTROL}

\section{Project Description:}

Upgrade and expand existing stormwater containment basin for increased containment and settling.

- Existing basins will be cleaned.

- Sediment will be disposed of as low level radioactive waste.

- The Overflow Pond will be expanded to contain run-off from the developed property equivalent to a 100-year storm event. 


\section{SITE DRAINAGE CONTROL}

\section{Project Description:}

Correct drainage related safety problems.

- Subsurface drainage will be installed in the large employee parking lot. 


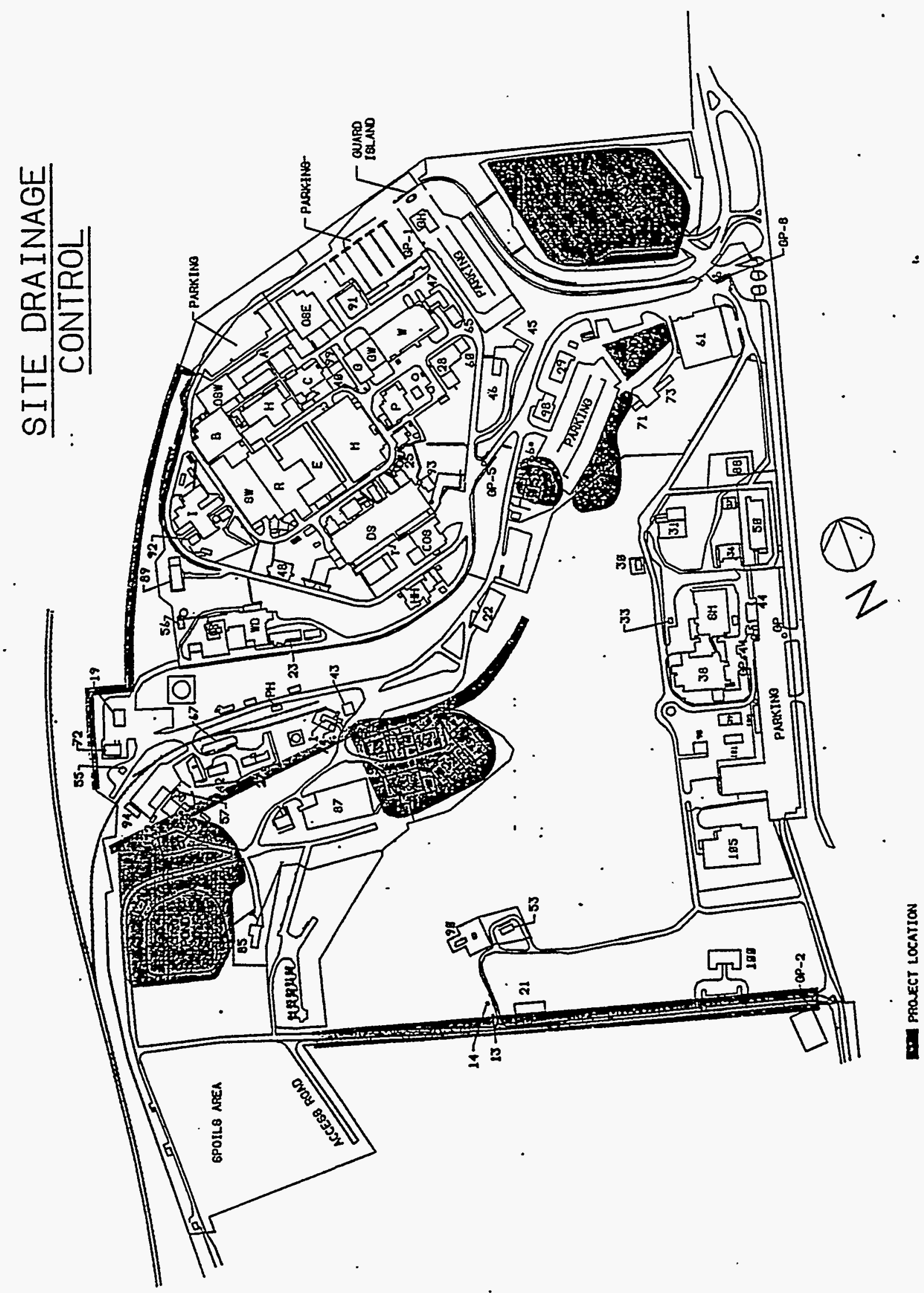


$\frac{1}{0}$
$\frac{1}{0}$
0
$\frac{1}{0}$
$\frac{1}{0}$
$\frac{1}{0}$
$\frac{1}{6}$

$\frac{\overline{0}}{\frac{0}{2}}$

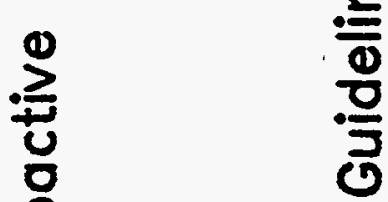

음

i

$\frac{.0}{\frac{5}{0}}$

$\stackrel{8}{0}$

4

$\frac{5}{2}$

范势

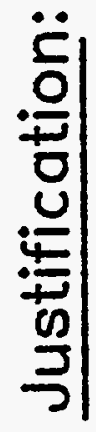

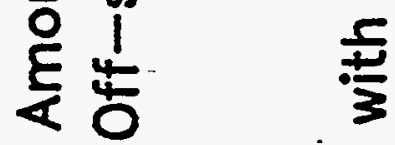

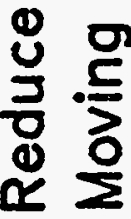

हे

$\frac{5}{3}$ 


\section{SITE DRAINAGE CONTROL}

Details of Justification:

Reduce Amount of Radioactive Material Moving Off-site.

- Uncontrolled stormwater erodes plutonium containing soil carrying it off-site.

- Stormwater containment allows plutonium containing soil to settle out on-site. 


\section{SITE DRAINAGE CONTROL}

Details of Justification:

Comply with DOE ALARA Guidelines.

- DOE Order 5400.5, "Radiation

Protection of the Public and the

Environment" requires that radioactive discharge be reduced to a level that is "As Low As Reasonably Achievable."

- Allowing present condition to continue does not meet ALARA. 


\section{SITE DRAINAGE CONTROL}

\section{Impacts of Funding:}

Not Funded:

The site may be in violation of DOE Order 5480.xx ALARA requirements.

Partial Funding:

Lower priority elements would be left undone. 


\section{MOUND PRIORITIZATION RATIONALE SITE DRAINAGE CONTROL}

OVERALL RATING 50

HEALTH \& SAFETY - 20

- $N / A$

ENVIRONMENTAL/WASTE MANAGEMENT - 50

- Regulatory compliance - generally in compliance, but potential serious violations are possible (erosion of known contaminated areas).

SAFEGUARDS \& SECURITY - 20

- N/A

PROGRAMMATIC - 20

- N/A 


\section{SITE DRAINAGE CONTROL}

Coșt Estimate Summary ( $\$ 000)$ :

Engineering, Design \& Inspection (6\% of construction) Construction..

$\$ 800$

A. Site Improvements

$\$ 13,300$

B. Contaminated Soil Disposal $\$ 3,900$ $\$ 9,400$

Sţandard Equipment Project \& Construction Management Contingency (20\% of Above)

300

2,900

Total Project Estimate

$\$ 17,300$ 
$\sum_{0}^{\frac{1}{0}}$

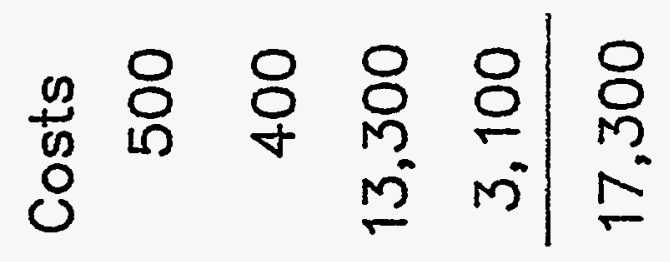

$\frac{x}{4}$

$\frac{1}{0}$
$\frac{1}{2}$
$\frac{\pi}{0}$
$\frac{1}{5}$

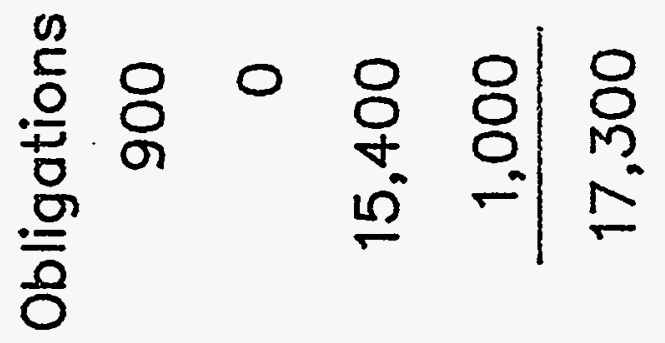

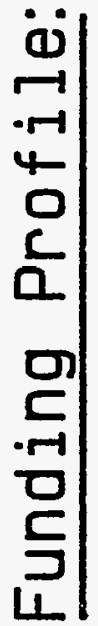

(1)

क क क ๙

乙と立 


\section{IEPA EN}

050 XDO- COPAETE IN 1906

2is suavit to DOE

100 DEs. CRIT. PREP. NE SEECTIOW \& HEGOTLATIOA

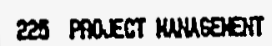

102 KDI

I05 PPACET AMTHOAIZLTION

110 NuAD DESIE CONThuCT

115 WuHTICIPATED AEQUIFEAENTS

120 HTORULU.

125 geacosc stuoy

130 STABILITY OF OVEFFLK PONO

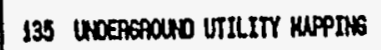

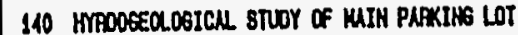

145 BEGIH DESIEH

I5O IITLE I DESISW

155 TIILE I PEVIEX

160 WuKTIGIPATED PEOUIFEVENTS

$162 \times 02$

173 TIIIE II DESIOW

265 PEATIT TO IHSTNL

160 TIME II PEVIEX

Jas UUMTICIPATES REOUIFEAENTS

190 coustauction bioning

195 oPen bros

$197 \mathrm{KDB}$

200 COHSTAUCTION COKTRLGT AMARO

170 PECEIVE PTI

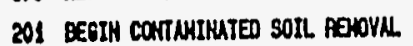

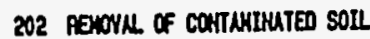

210 BEBIH COKSTAUCTION

215 constauctiot

216 UUMTICIPATED REQUIPEEETS

¿20 COAPLETE COKSTHUCTIOH

230 UUHTICIPATED FEOLIFEIFTIS

232 KDI

25 BEGIH OPERAIIOH

\section{Legend}

SITE DRAINAGE .CONTROL

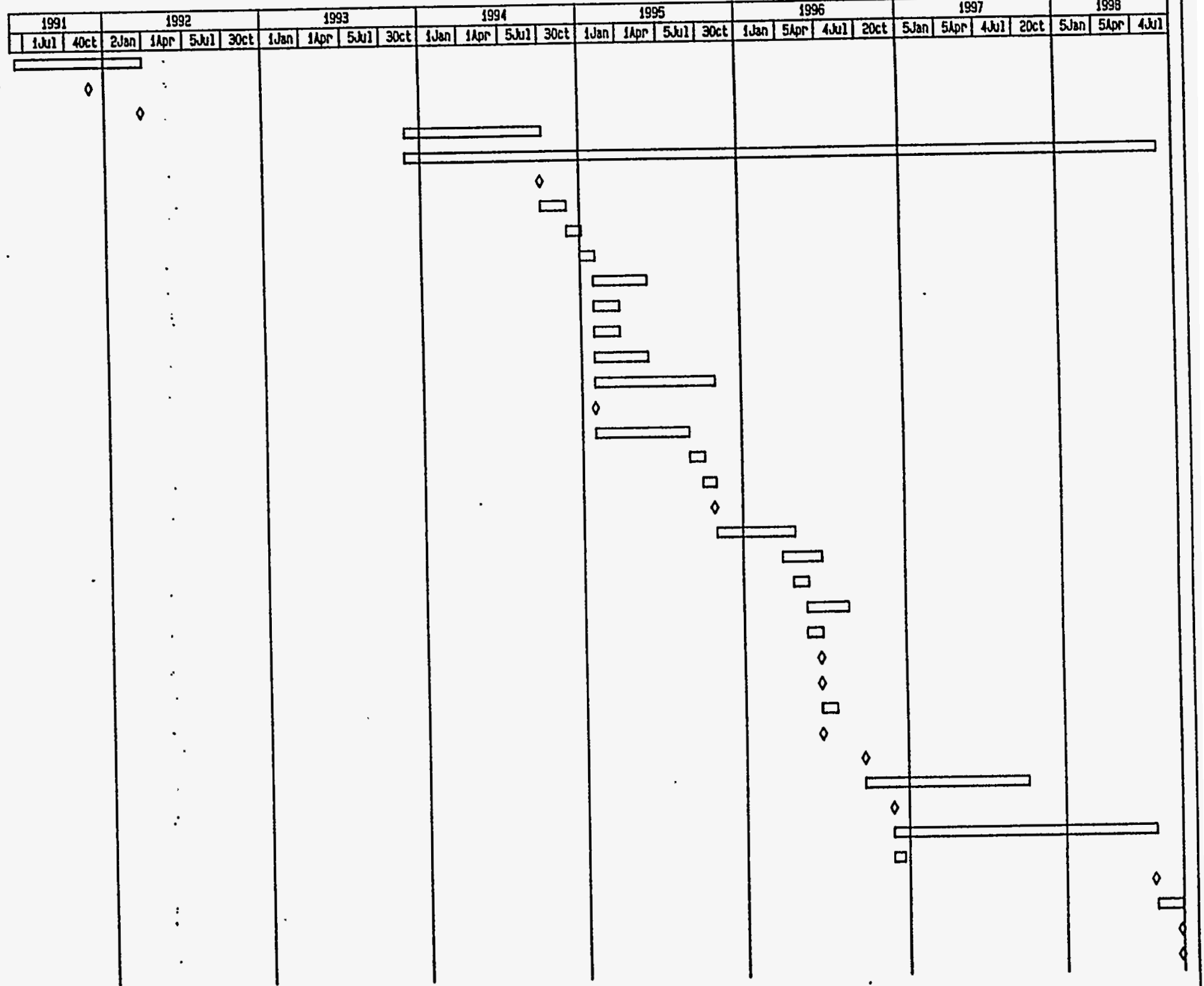

\begin{tabular}{|l|l|l|}
\hline Pro/ect: 50C & SOC & Date: 13Jan92 16:55 \\
\hline
\end{tabular} SITE DALIMGE CONTAO

\begin{tabular}{|l|l|}
\hline Pag̣e: 1 & Ess6 Enginaering Project Hanageaent Support
\end{tabular} 


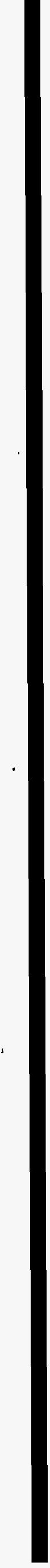

